\title{
Northern Hemisphere temperature patterns in the last 12 centuries
}

\author{
F. C. Ljungqvist ${ }^{1,2,3}$, P. J. Krusic ${ }^{3,4}$, G. Brattström ${ }^{3,5}$, and H. S. Sundqvist ${ }^{3,4}$ \\ ${ }^{1}$ Department of History, Stockholm University, 10691 Stockholm, Sweden \\ ${ }^{2}$ Centre for Medieval Studies, Stockholm University, 10691 Stockholm, Sweden \\ ${ }^{3}$ Bert Bolin Centre for Climate Research, Stockholm University, 10691 Stockholm, Sweden \\ ${ }^{4}$ Department of Physical Geography and Quaternary Geology, Stockholm University, 10691 Stockholm, Sweden \\ ${ }^{5}$ Department of Mathematics, Stockholm University, 10691 Stockholm, Sweden \\ Correspondence to: F. C. Ljungqvist (fredrik.c.1@historia.su.se)
}

Received: 30 September 2011 - Published in Clim. Past Discuss.: 13 October 2011

Revised: 21 December 2011 - Accepted: 22 December 2011 - Published: 3 February 2012

\begin{abstract}
We analyse the spatio-temporal patterns of temperature variability over Northern Hemisphere land areas, on centennial time-scales, for the last 12 centuries using an unprecedentedly large network of temperature-sensitive proxy records. Geographically widespread positive temperature anomalies are observed from the 9th to 11th centuries, similar in extent and magnitude to the 20th century mean. A dominance of widespread negative anomalies is observed from the 16th to 18th centuries. Though we find the amplitude and spatial extent of the 20th century warming is within the range of natural variability over the last 12 centuries, we also find that the rate of warming from the 19th to the 20th century is unprecedented in the context of the last $1200 \mathrm{yr}$. The positive Northern Hemisphere temperature change from the 19th to the 20th century is clearly the largest between any two consecutive centuries in the past 12 centuries. These results remain robust even after removing a significant number of proxies in various tests of robustness showing that the choice of proxies has no particular influence on the overall conclusions of this study.
\end{abstract}

\section{Introduction}

A number of Northern Hemispheric (NH) temperature reconstructions covering the last 1-2 millennia, using temperaturesensitive proxy data, have been made to place the observed 20th century warming into a long-term perspective (Ammann and Wahl, 2007; Briffa, 2000; Christiansen and Ljungqvist, 2011; Cook et al., 2004; Crowley and Lowery, 2000; D'Arrigo, 2006; Esper et al., 2002; Hegerl et al., 2007; Jansen et al., 2007; Jones et al., 1998; Jones and Mann, 2004; Juckes et al., 2007; Ljungqvist 2010; Mann et al., 1999, 2008, 2009; Mann and Jones, 2003; Moberg et al., 2005; Osborn and Briffa, 2006). Temperature variability during the last 1-2 millennia on a regional scale has been studied for the Arctic region by Kaufman et al. (2009), for eastern China by Ge et al. (2006), Ge et al. (2010), Wang et al. (2007) and Yang et al. (2002), for Europe by Büntgen et al. (2011), Goosse et al. (2006), Goosse et al. (2012), Guiot et al. (2010) and Guiot (2012), for the Mediterranean region by Luterbacher et al. (2012), for the Tibetan Plateau by Yang et al. (2003) and for southern South America by Neukom et al. (2011). These studies generally agree on the occurrence of warmer conditions ca. 800-1300 AD and colder conditions ca. $1300-1900 \mathrm{AD}$, followed by a strong warming trend in the 20th century (Jansen et al., 2007). The earlier warm period is usually referred to as the Medieval Warm Period (MWP) or Medieval Climate Anomaly (MCA) (Bradley et al., 2003; Broecker, 2001; Diaz et al., 2011; Esper and Frank, 2009; Hughes and Diaz, 1994) whereas the later colder period is usually referred to as the Little Ice Age (LIA) (Grove, 1988; Juckes et al., 2007; Matthews and Briffa, 2005; National Research Council, 2006; Wanner et al., 2008, 2011). Related to this issue is the question of whether or not the current warmth has exceeded the level and geographic extent of the warmth in the last millennium.

Placing the level of the recent warming in context to past warmth does not alone tell us anything about the physical processes responsible for either. Yet, having the ability to distinguish, on a hemispheric-scale, between a homogeneous and a heterogeneous climate state is fundamental to 
our understanding of plausible climate forcings. It has been suggested that only large-scale climate averages reflect a response to external forcing (Jansen et al., 2007) and recent studies of reconstructed global temperature patterns imply that a dynamic response of climate variability due to natural radiative forcing is detectable (Mann et al., 2009). At the same time, it has been argued that the use of too few noisy and poorly replicated proxies precludes a satisfactory assessment of spatial temperature anomalies, particularly in medieval times (Esper and Frank, 2009; Broecker, 2001). Therefore, it is essential to refine our knowledge of the temporal evolution of spatial climate variability. We suggest this cannot be satisfactorily done without considering all the available proxy evidence.

Recent hemispheric-scale, temperature reconstructions over the past millennium, with two notable exceptions (Mann et al., 1999, 2009), have focused on reconstructing temperatures in the time domain only, an understandable consequence resulting from few and sparsely distributed highresolution proxies that can be calibrated directly against instrumental observations. The unique approach of Mann et al. $(1999,2009)$ attempts to overcome this problem by taking advantage of statistically determined spatial teleconnections between instrumental temperature fields and temperature, precipitation or drought sensitive proxy data. An example is the strong correlation between the moisture-sensitive tree-ring series in the American Southwest and sea surface temperatures in the tropical Pacific ENSO region (Wilson et al., 2010). This method relies heavily on the assumption that both the spatial and temporal relationships found between the modern (proxy vs. climate) measurements have remained constant through time and that these relationships are linear. Nevertheless, due to the method, the Mann et al. (2009) reconstructed medieval period is still based on relatively few, spatially well distributed, proxies. The numbers of Northern Hemisphere proxies, extending beyond $1000 \mathrm{AD}$, used in previous global scale multi-proxy temperature reconstructions are shown in Table 1. Arguably, a substantially denser proxy network should produce a more robust reconstruction. This can be done if one accepts proxies with lower temporal resolution and if the proxies used are constrained to be indicators of local temperature. However, the decision to include low-resolution proxies results in the loss of temporal detail (resolution) and the inability to produce a temperature calibrated reconstruction. We suggest these drawbacks are not detrimental to the exercise and in fact permit accurate descriptions of climate variability in both time and space on centennial time-scales.

\section{Proxy data and method}

Here, we present a new reconstruction of the spatio-temporal patterns of centennial temperature variability over the $\mathrm{NH}$ land areas for the last twelve centuries based on 120 proxy

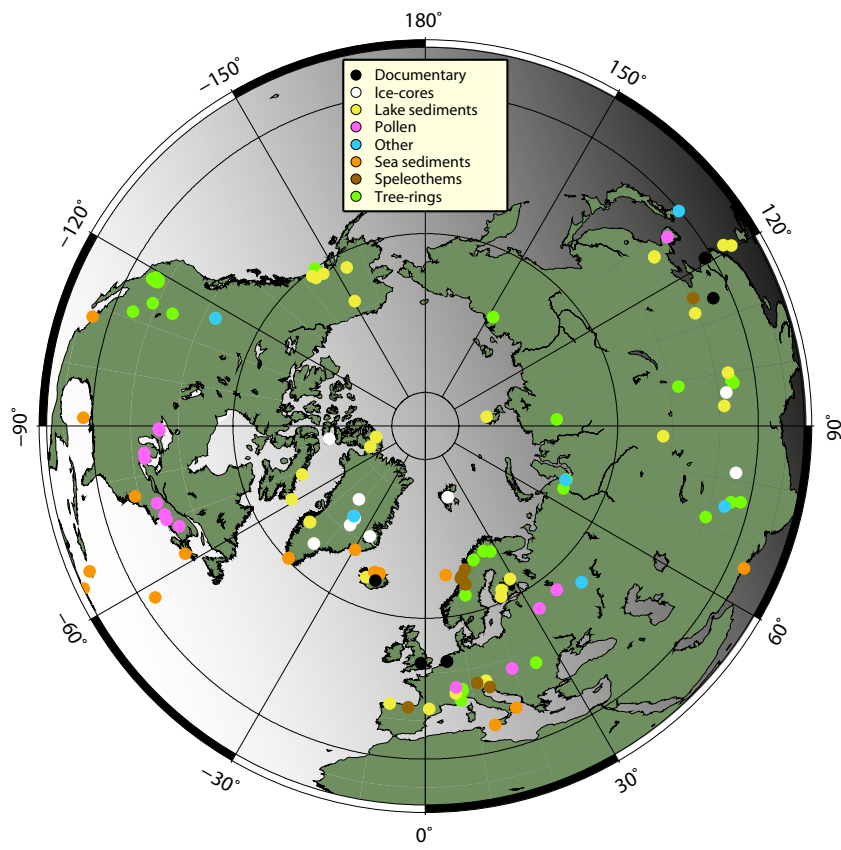

Fig. 1. Type and location of all 120 proxy records used in this study (see Table 1 for details). Note, that a few pairs of proxies share the same geographical position but are based on different archives. Not depicted on this map is the Indo-Pacific Warm Pool sea sediment record located at latitude $3.53^{\circ} \mathrm{S}$ and longitude $119.27^{\circ} \mathrm{W}$.

records (Fig. 1; Table A1). An extensive search of the literature for proxy records possessing annual to sub-centennial resolution covering at least the last millennium, and considered by their authors to be temperature sensitive, was conducted. The proxies are retrieved from a wide range of archives including, but not limited to, ice-cores, pollen, marine sediments, lake sediments, tree-rings, speleothems and historical documentary data (Table A1). We concede that each proxy type has its inherent strengths and weaknesses as a palaeo-thermometer. Numerous books and articles describe the use and interpretation of the proxy types used in this experiment. Therefore, we forego a lengthy discussion on climate proxies here and instead refer the reader to Bradley (1999) and Jones et al. (2009), and the references within, for a comprehensive overview of palaeoclimatology.

The data are also diverse not only in their type, resolution and location but also in the temperature signal they are reported to contain. Most high-latitude proxies primarily record summer temperatures while most low-latitude proxies primarily record annual mean temperatures. The midlatitude proxies may have either a summer or annual mean temperature signal. Only eight of the proxies used are purported to be expressions of winter temperature.

To obtain a network of widely distributed temperature proxies we accepted records having as few as two data points per century. The decision to use low-resolution proxy data confines our analyses to no less than centennial variations, 
Table 1. Number of Northern Hemisphere proxies extending beyond 1000 AD used in previous hemispheric or global scale, multi-proxy, temperature reconstructions. The reconstructions by Juckes et al. (2007), Loehle (2007) and Mann et al. (2009) include Southern Hemisphere proxies, from these studies only those proxies from the Northern Hemisphere are counted.

\begin{tabular}{lrrr}
\hline Study & Region & $\begin{array}{r}\text { Number with } \\
\text { annual resolution }\end{array}$ & Total \\
\hline This study & $90-0^{\circ} \mathrm{N}$ & 49 & 120 \\
\hline Mann et al. (2008) & $90-0^{\circ} \mathrm{N}$ & 30 & 46 \\
Mann et al. (2009) & $90-0^{\circ} \mathrm{N}$ & 30 & 46 \\
Christiansen and Ljungqvist (2011) & $90-30^{\circ} \mathrm{N}$ & 21 & 40 \\
Ljungqvist (2010) & $90-30^{\circ} \mathrm{N}$ & 16 & 30 \\
Moberg et al. (2005) & $90-0^{\circ} \mathrm{N}$ & 8 & 18 \\
Loehle (2007) & $90-0^{\circ} \mathrm{N}$ & 1 & 14 \\
Ammann and Wahl (2007) & $90-0^{\circ} \mathrm{N}$ & 12 & 12 \\
Crowley and Lowery (2000) & $90-0^{\circ} \mathrm{N}$ & 6 & 12 \\
Juckes et al. (2007) & $90-0^{\circ} \mathrm{N}$ & 9 & 12 \\
Mann et al. (1999) & $90-0^{\circ} \mathrm{N}$ & 12 & 12 \\
Osborn and Briffa (2006) & $90-0^{\circ} \mathrm{N}$ & 8 & 10 \\
Hegerl et al. (2007) & $90-30^{\circ} \mathrm{N}$ & 7 & 8 \\
Mann and Jones (2003) & $90-0^{\circ} \mathrm{N}$ & 5 & 8 \\
D'Arrigo et al. (2006) & $90-20^{\circ} \mathrm{N}$ & 6 & 6 \\
Esper et al. (2002) & $90-20^{\circ} \mathrm{N}$ & 6 & 6 \\
Briffa (2000) & $80-45^{\circ} \mathrm{N}$ & 3 & 3 \\
Jones et al. (1998) & $90-0^{\circ} \mathrm{N}$ & 3 & 3 \\
\hline
\end{tabular}

a The same dataset is used in Mann et al. (2008, 2009) which includes precipitation and drought proxies that correlate to temperature variability at some location on the globe though not necessarily over the site of the proxy.

but delivers substantially larger spatial coverage, particularly, prior to ca. $1400 \mathrm{AD}$. Since many of the proxies used cannot be reliably calibrated into temperatures we use centennial mean anomalies normalized with respect to the 11 th-19th centuries. This is the period fully covered by all 120 proxies.

For proxies sampled at time steps greater than one year a linear interpolation is used to produce an annually resolved time-series that is then smoothed with a 167-yr spline which has a frequency response similar to a 100-yr moving average. Fitting the spline to the interpolated values minimizes undesirable effects of the linear interpolation step, particularly for those proxies with few data points per century. The resulting splines are then passed through a 100-yr box filter, lagged $25 \mathrm{yr}$, producing a new time-series of 45 centennial means from $850 \mathrm{AD}$ to $1950 \mathrm{AD}$ for each proxy (Figs. A1-A2). The 45 centennial means from each proxy record are then normalized by their mean and standard deviation over the 11 th to 19 th centuries (1000 AD to $1899 \mathrm{AD})$. The twelve normalized centennial mean anomalies, located in the middle of each whole century (e.g., $850 \mathrm{AD}, 950 \mathrm{AD}$, $1050 \mathrm{AD}, \ldots, 1950 \mathrm{AD})$, are used for the spatial comparisons in Figs. 2-3. The 45 normalized centennial means are used for producing the time-series plots in Fig. 4. See Appendix A for details.

The spatial-temporal evolution of anomalies is dynamically displayed in an 1101-yr animation from $850 \mathrm{AD}$ to
1950 AD. At every proxy location an Akima spline (Akima, 1970 ) is fit to each proxy's 45 centennial mean values (raw and weighted) producing a smooth, centennial trend, interpolation with a time step of one year. The four animations produced, available as an electronic Supplement, are (i) the filtered spline values, (ii) the gridded, filtered spline values, (iii) the proxy-centred, weighted mean, filtered spline values, and (iv) the gridded, proxy-centred, weighted mean, filtered spline values. The first purpose of this exercise is to demonstrate how the weighted mean and gridding algorithms affect the transformation of the raw data. The Akima spline is very efficient in handling discontinuous time series data to produce continuous interpolations without inducing spurious wiggles because no parametric curve form is assumed and only the local data nodes are taken into account (Akima, 1970). Secondly, producing these 1101 slices of the spatial field permits one to examine the temporal stability of both proxy-local and proxy extra-local patterns produced by the analysis.

\subsection{Weighted anisotropic averaging and gridding}

The real spatial variability of centennial mean temperatures is certainly more coherent than the centennial mean anomalies shown in Fig. 2. We infer from Jones et al. (1997) that the global-mean correlation decay length, for unforced centennial temperature variability, is at least $\sim 2000 \mathrm{~km}$ and 

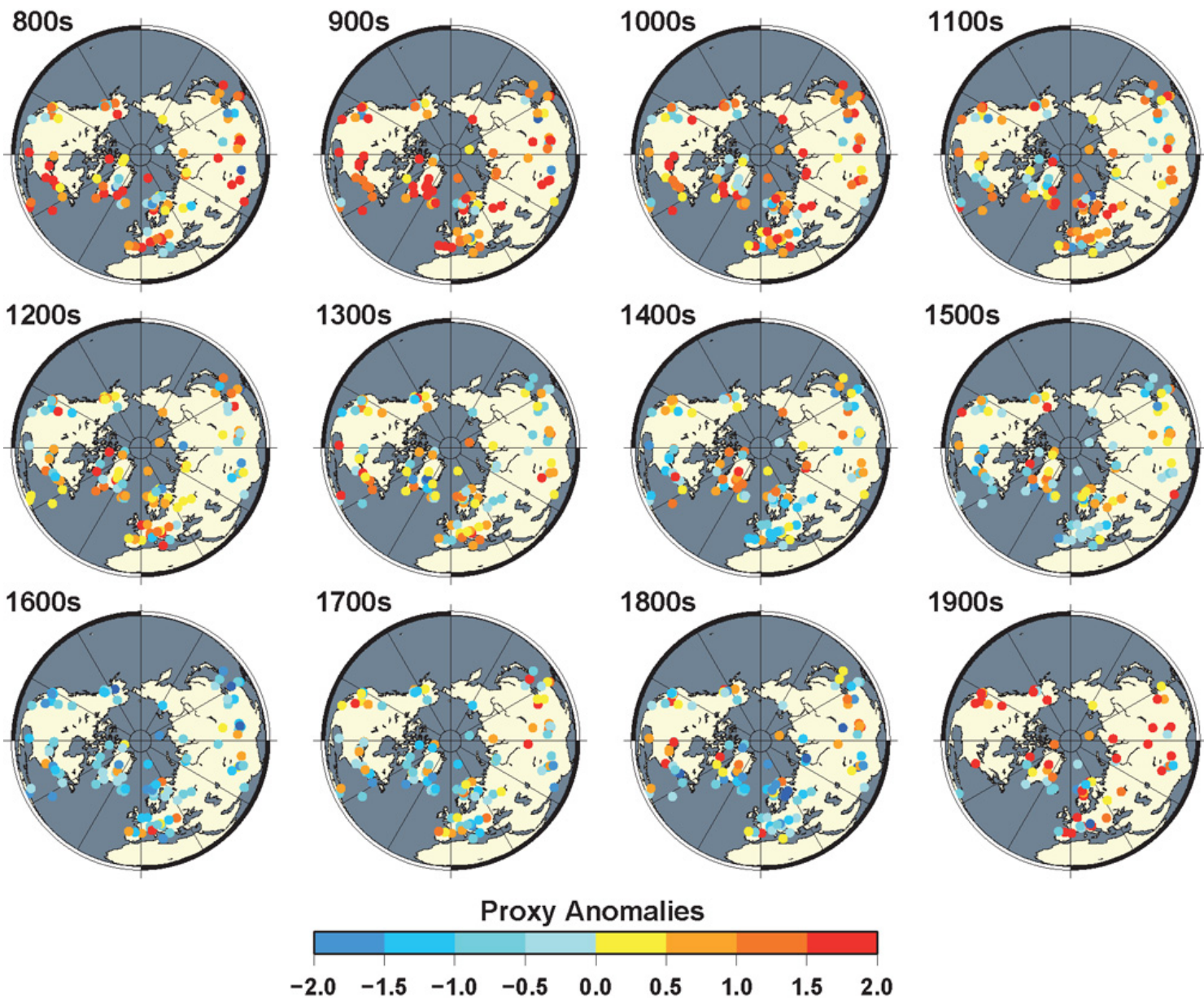

Fig. 2. Raw, centennial, proxy anomaly values. Anomalies are shown relative to the centennial mean and standard deviation over the 11 th-19th centuries. The colour scale is truncated at -2 and 2.

decreases from low to high latitudes. The correlation decay length is the distance at which spatial temperature correlations between meteorological stations, on average, falls to $\approx 0.37$ (see Appendix A for more details). Due to the diversity of proxies used it is more relevant to look into how groups of neighbouring proxies behave than to focus on any individual record. This approach is not that dissimilar to the approach taken in the evaluation of Global Circulation Models by using their ensemble means (Annan and Hargreaves, 2011; Collins, 2007; Knutti et al., 2010; Masson and Knutti, 2011; Tebaldi and Knutti, 2007).

Compared to instrumental data (Appendix C), the proxy records contain more noise; therefore, spatial averaging of proxy anomalies is reasonable. To obtain a clearer view of the spatial patterns of temperature variability provided by the proxies we first applied a weighted averaging to the centennial mean anomalies, centred over each proxy location, for all 45 centennial means. A Gaussian weight function that decreases from 1 , at the proxy node, to $e^{-2} \approx 0.14$ at the search periphery was used to compute a weighted mean.
Proxy centred, weighted mean, centennial values are computed only if a proxy has two or more neighbours with data for the same century and those neighbours lie within a meridionally defined, anisotropic, search radius that decreases from $2000 \mathrm{~km}$ at the equator to $1000 \mathrm{~km}$ at the North Pole. Gridding of these spatially weighted, proxy-centred, centennial means was performed using a modified near neighbour gridding algorithm that requires at least 3 proxies within the search radius of each node of a $1^{\circ} \times 1^{\circ}$ Cartesian grid over the Northern Hemisphere. The grid values are calculated from the weighted-mean centennial proxy values using the same Gaussian weight and anisotropic search functions described above. Though the oceans have been masked on the maps, coastal marine proxy records may contribute to the land area grid (see Appendix A for more details). The gridding procedure smoothes small-scale variations as seen in the individual proxies (in Fig. 2) and retains only those variations of the proxy means that are spatially distinct (Fig. 3). 

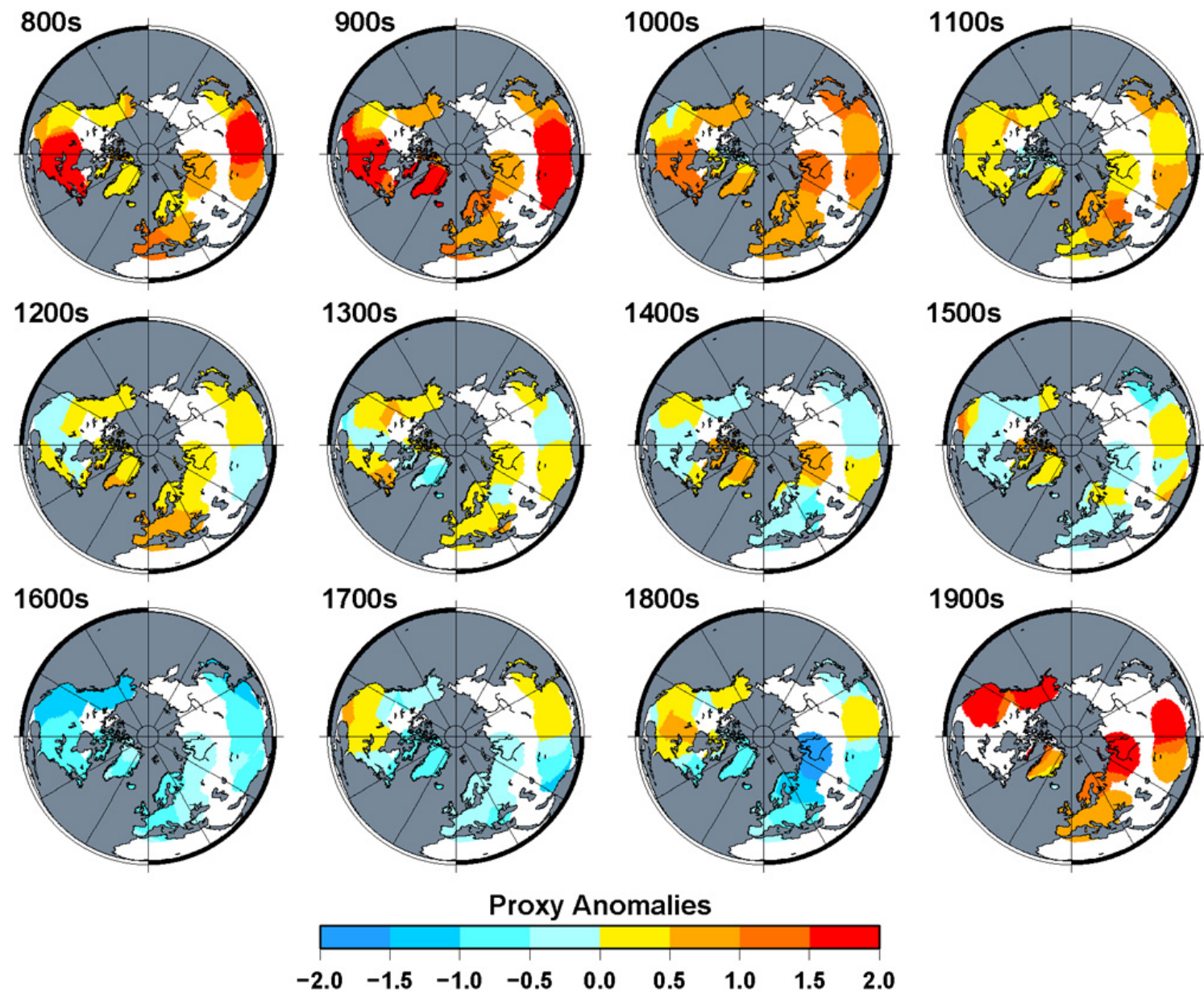

Fig. 3. Gridded, weighted, centennial proxy anomalies derived from the data shown in Fig. 1. Anomalies are shown relative to the 11th-19th century reference period. The colour scale is truncated at -2 and 2 .

\subsection{Test of robustness}

To test the robustness of the proxy data used and the observed spatial patterns they produce we undertook a number of experiments, like the one shown in Fig. 3, using different subsets of the proxies. The results from these experiments are provided in the accompanying supplement to this article. The five different experiments performed are: (i) excluding one proxy data type at a time (ii) using only those proxies that begin before $816 \mathrm{AD}$ and end after $1984 \mathrm{AD}$ (iii) using only proxies with 4 or more, and also with 10 or more, observations per century (iv) requiring that each proxy series used must have data coverage up to 1995 and (v) excluding the 43 proxy series that have either a negative correlation to the mean time-series of their proxy centred, within-searchradius, neighbours or less than two within-search-distance neighbours. No result from of these five experiments significantly changes our main observations regarding the spatiotemporal patterns of past temperature variability. The results of these experiments are only shown in the supplement to this article in Figs. S1-S13 with supporting text.

\section{Results}

The spatial and temporal patterns of centennial temperature proxy anomaly values at each proxy location, for the last twelve centuries, are illustrated in Fig. 2. In addition to the large-scale patterns that clearly emerge (a dominance of warm anomalies in the 9th-11th centuries, cold anomalies in the 17th century, warm again in the 20th century) there is notable small-scale spatial variability among the individual proxies.

Temperatures from the 9th to 12 th centuries are generally above the long-term mean, gradually cooling to below the mean in the 16th to 19th centuries and reaching a maximum cooling in the 17 th century. The 20th century warming raised the centennial mean back to a level comparable to that of the 9th to 11th centuries. The resulting maps (Fig. 3) reveal remarkable large-scale spatial coherency of warm and cold conditions over the NH land areas for the past twelve centuries. The dominance of warm anomalies during the MWP and cold anomalies during the LIA is substantiated by results from the sign test (Fig. B1) that shows where and when 


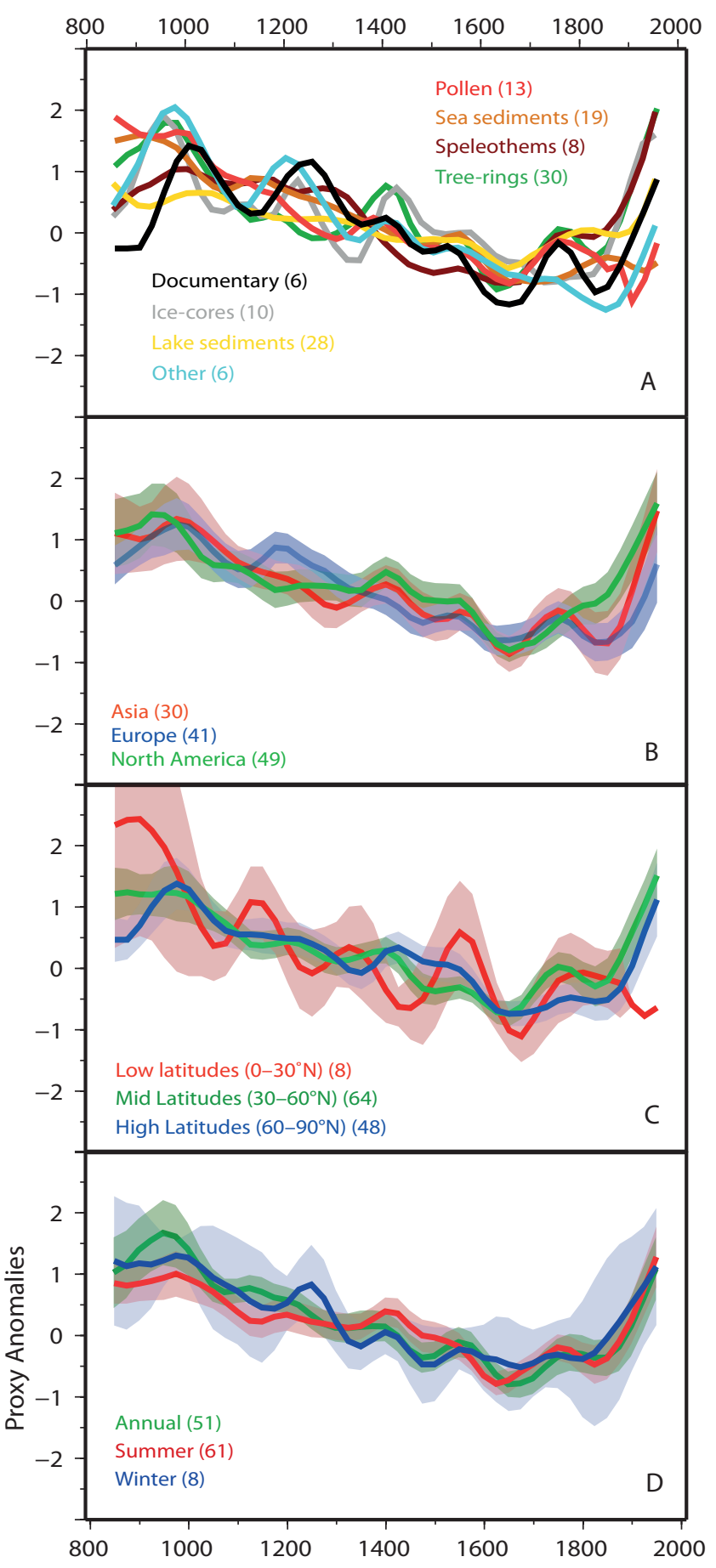

Fig. 4. Mean time-series of centennial proxy anomalies separated by: (A) data type, (B) continents, (C) latitude, (D) seasonality of signal. The curves in (B-D) show the mean and moving block bootstrap confidence intervals ( \pm 2 standard error) (Wilks, 1997). The numbers in parentheses indicates the number of proxies in each category. there is significant agreement between the sign, positive or negative, of the proxies within their search radius (for more details see Appendix B).

The tests of robustness (see the accompanying supplement to this article) clearly reveal that when the spatial coverage decreases as proxies are excluded, the remaining spatial patterns of warm and cold anomalies are not substantially different from when all proxies are used. For example, the requirement that the proxies used must have data up to 1995 reduces the number of usable proxies to 34 yet, for the limited areas still covered, the overall patterns remain the same (compare Fig. 3 with Fig. S12). Together the various experiments indicate that the observed large-scale spatial patterns of reconstructed normalized temperature anomalies, as seen in Fig. 3, are a robust feature of NH temperature variability over the last twelve centuries. Such an approach to assessing robustness is only possible with a large number of proxy records. The averaged centennial mean anomalies and their block bootstrap confidence intervals (Wilks, 1997), expressed as \pm 2 standard errors, for subsets of proxies grouped by type, continent, latitude and seasonality of signal are presented in Fig. 4. Essentially, the same overall temporal trends, with the exception of those proxy groups that have insufficient 20th century data (mainly pollen and sea sediment records), are found.

Computing the rate of change within the last twelve centuries produces eleven maps of centennial first differences (Fig. 5). These maps show that the greatest rate of change over a widespread area was between the 19th and 20th centuries where strong warming is observed over nearly all areas with sufficient data. Comparable rates of warming between consecutive centuries are only seen for limited regions such as over Greenland from the 9th to the 10th century. The second largest geographical extensive warming between consecutive centuries occurs from the 17th to the 18th centuries when almost all of North America, and much of the eastern half of Asia, warmed. A cooling trend is seen for most regions between the 10th and 13th centuries. The most widespread cooling between two consecutive centuries is from the 16th to the 17th.

\section{Discussion}

The density of proxies is comparatively high over Europe, Greenland, China and parts of North America, implying that the observed patterns over those regions are the most robust. The coverage is sparse over interior Asia and nonexistent in North Africa and the Middle East. Consequently, these areas are either poorly replicated or left blank on the maps which is unfortunate as these are regions important to understanding teleconnection patterns in the climate system (e.g., El Niño/La Niña-Southern Oscillation and drought over southwestern North America, North Atlantic Oscillation and drought over China) (Graham et al., 2011; Lee and Zhang, 


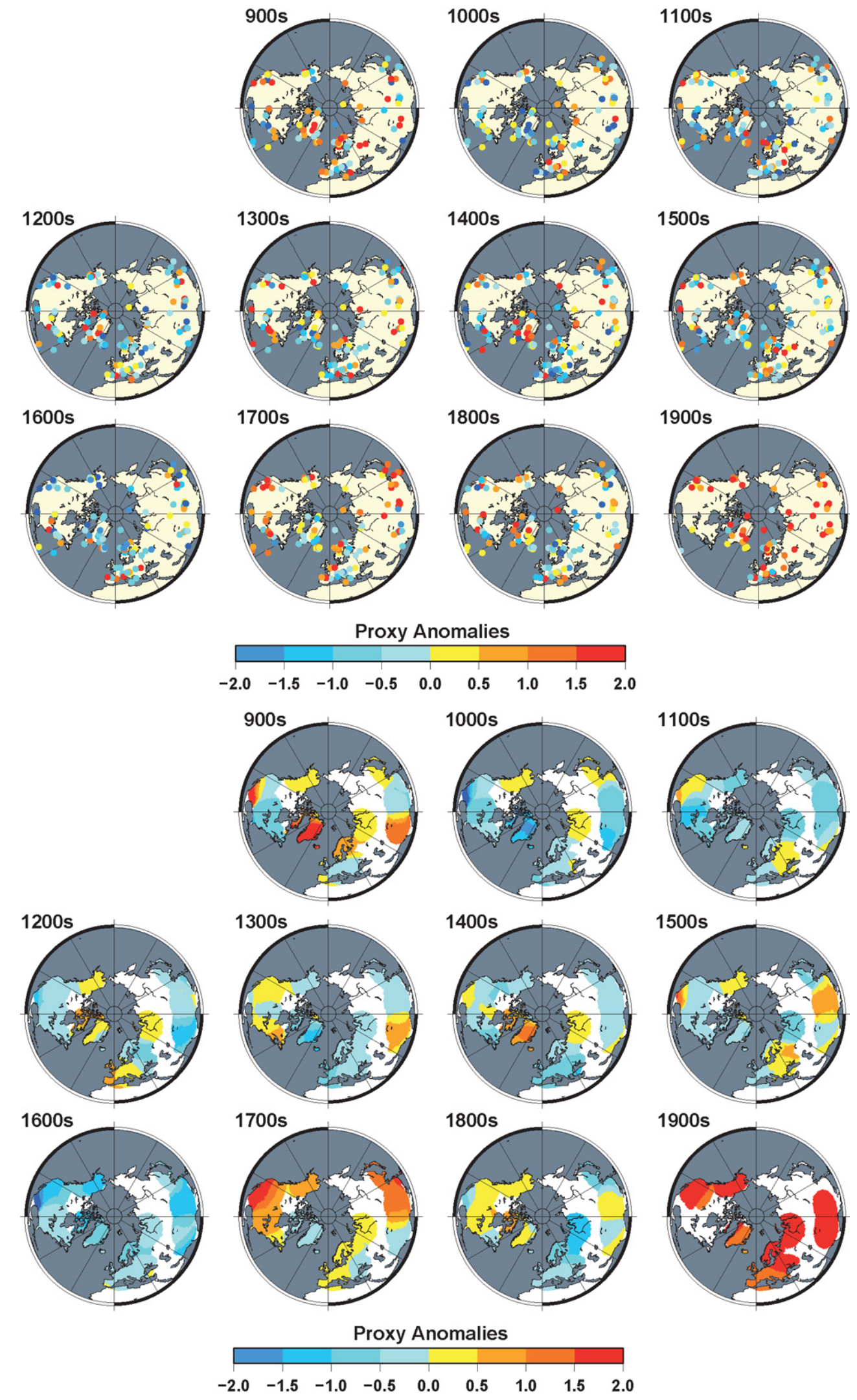

Fig. 5. Centennial first-differences between each century and the previous. Upper panel: differences for raw centennial proxy anomaly values as shown in Fig. 2. Lower panel: gridded, weighted, centennial anomaly values for the same data. The colour scale in both panels is truncated at -2 and 2 . 

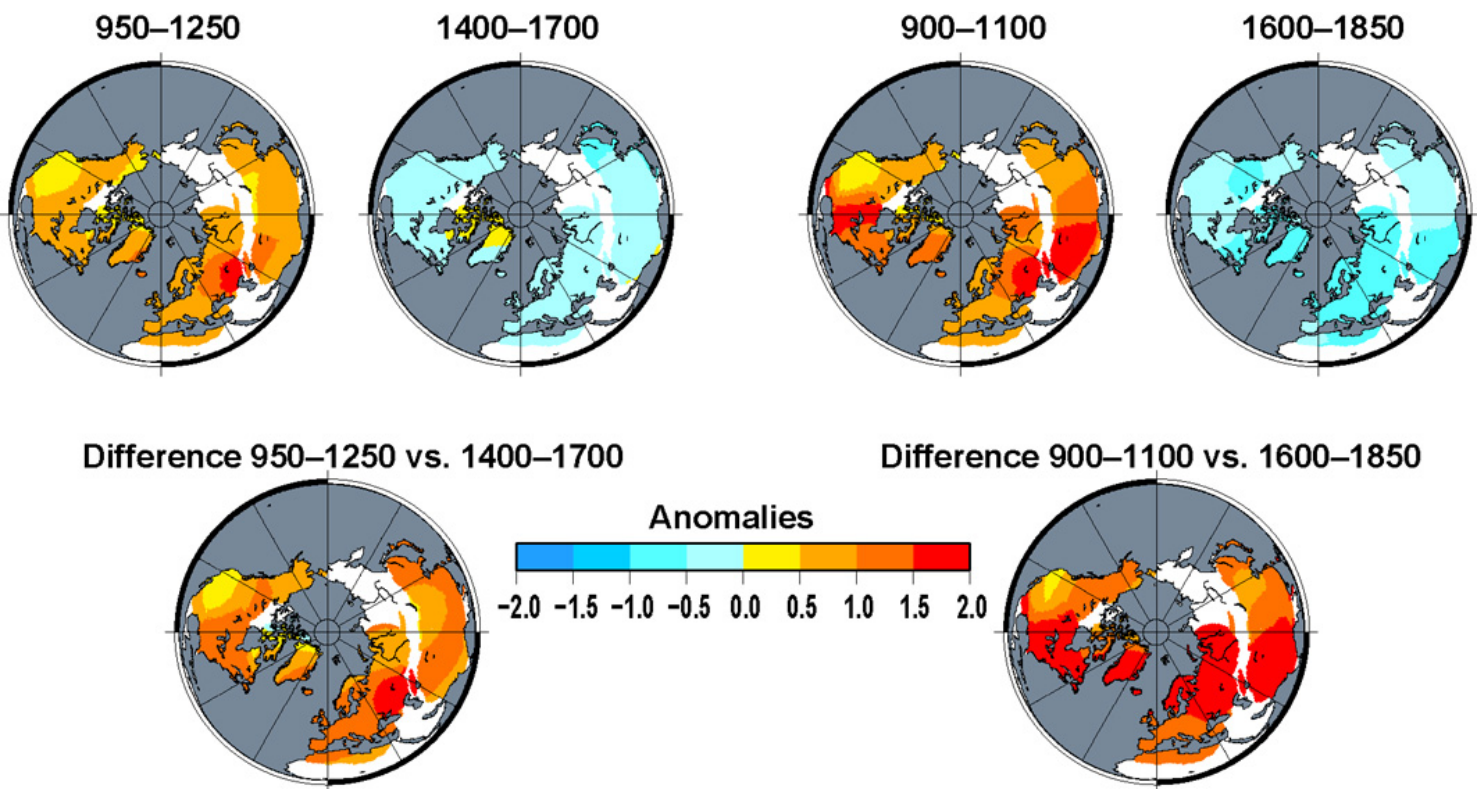

Fig. 6. The mean and differences in anomaly values from our spatial reconstruction using the same two MWP and LIA periods defined in Mann et al. (2009).

2011). More temperature proxies are thus needed, particularly in the interior of Asia, the Middle East and northern Africa to firmly assess past climate variability. It is also essential to reconstruct climate patterns in the Southern Hemisphere (SH) and over the oceans in order to better understand the dynamics of internal variability and external forcings on global climate. This is presently difficult to achieve due to the scarcity of marine and SH proxy data (see, e.g., Neukom and Gergis, 2012).

Our reconstructed spatial anomalies cannot directly be compared with the calibrated climate field reconstruction by Mann et al. (2009), but we observe that our reconstructed patterns are not in disagreement. It is worth noting that our anomaly differences in the 9th to 11th centuries looks very similar to the MWP-LIA difference in Mann et al. (2009) when the influence of their 1961-1990 baseline period is removed (Fig. 6).

Analyses of instrumental data (Brohan et al., 2006) shows that the last decade of the 20th century was much warmer than the 20th century mean nearly everywhere over NH land areas with sufficient data (Fig. C1). Moreover, the first decade of the 21 st century was even warmer in most locations, thus, providing evidence that the long-term, largescale, $\mathrm{NH}$ warming that began in the 17th century and accelerated in the 20th century has continued unabated (see Appendix $\mathrm{C}$ for more details).

The warming from the 17th to the 20th century did not occur uniformly or simultaneously over all NH land regions (Figs. 3, 5). Almost all of North America, western Europe and much of central and eastern Asia warmed from the 17th to the 18th century but not Greenland, eastern Europe and northwestern Asia. Notable cooling occurred from the 18th to 19th century in northern Europe and much of Asia except in the south to southwest. This cooling caused the 19th century to be the coldest over much of northwestern Eurasia. Only from the 19th to the 20th century is warming observed over nearly all areas. Notable changes between consecutive centuries are also observed before the 17th century but these are more characterised by variability within smaller regions and no clear large-scale spatial patterns emerge apart from the overall long-term cooling from the 10th to the 17 th century.

\section{Conclusions}

A principal importance of this study is that it helps demonstrate that the science of paleoclimatology, particularly the collection and interpretation of proxy records, is capable of producing a body of evidence that can reveal many details of climate variability over time and space. Our results show, in a comparative manner, the degree to which the various proxy types can be used to assess regional temperature variability on centennial time-scales. We conclude that during the 9th to 11th centuries there was widespread $\mathrm{NH}$ warmth comparable in both geographic extent and level to that of the 20th century mean. Our study also reveals that the 17th century was dominated by widespread and coherently cold anomalies representing the culmination of the LIA. Understandably, the centennial resolution of this study precludes direct comparison of past warmth to that of the last few decades. However, our results show the rate of warming from the 19th to the 20th century is clearly the largest between any two consecutive centuries in the past $1200 \mathrm{yr}$. 
It is clear that not all proxies from the same local need exhibit the same centennial signal to infer a robust, regional, climate pattern provided a sufficient number of proxies are available to compute a meaningful average. For the same reason it is also clear that the choice of proxies used does not significantly change the overall conclusions of this study. Even after removing a significant number of proxies within the various tests of robustness, the significant spatial patterns of warm and cold anomalies remain the same as when all 120 proxies are used. This implies that our results depicting the large-scale spatial-temporal patterns of warm and cold conditions, as revealed by using all available temperature sensitive proxy records, can be considered as a robust reconstruction of the thermal conditions over the Northern Hemisphere over the last 12 centuries.

\section{Appendix A}

\section{Methods and materials}

\section{A1 Proxy data}

The peer-reviewed literature was systematically searched for all reported temperature proxy records spanning at least the 11 th to 19 th centuries and considered by their authors to be primarily a quantitative measure of local and/or regional temperature variability. Only records with at least two observations per century were considered. The large majority of raw data were either obtained from public databases (e.g., http: //www.ncdc.noaa.gov/paleo/ and http://www.pangaea.de/) or by direct request from their authors. Those data that could not be acquired in either of the aforementioned ways were obtained by digitizing the figures where the data were published. The longitude, latitude, proxy type, sample resolution, seasonality and original reference of all 120 proxy records used are given in Table A1. The location of all the different proxy records is given in Fig. 1.

The proxy data are divided into eight different categories: (1) Documentary, (2) Ice-core, (3) Lake sediments, (4) Pollen, (5) Sea sediments, (6) Speleothems, (7) Treerings, and (8) Other. All types of information from historical records used to reconstruct past temperatures are included in the category Documentary. The category Ice-core only includes $\delta^{18} \mathrm{O}$ ice-core records. In the category Lake sediments all archives from lakes and peat bogs, excluding any pollen records, are included. The Pollen category includes all pollen records regardless of whether the pollen is derived from lake sediments, peat layers, ice-cores, or sea sediments. Sea sediments include all sediment records that are stated to reflect sea surface temperature. The category Speleothems includes $\delta^{18} \mathrm{O}$ records and annual layer thickness from speleothems. The category Tree-rings includes tree-ring width and maximum latewood density (MXD) chronologies but not stable isotope records. Those proxies that did not fit into one of the above seven data categories were placed in the category
"Other". This data category includes fossil wood remains, indicating changes in tree-line elevation, ${ }^{13} \mathrm{C}$ tree-ring records and $\mathrm{a} \mathrm{N}_{2}$ and $\mathrm{Ar}$ isotopic ice-core record.

For the purpose of simplification, we have collated the proxy data into three categories of seasonal temperature response: annual, winter, and summer temperature. Documented spring and early autumn temperature proxies are considered summer season records. Proxies expressing a late autumn season signal are included in the winter category. Records reflecting only spring or autumn temperature were so few that it was deemed inadequate to create separate categories for them. If no information on a proxy record's seasonality was available, we assumed the proxy to be an annual mean temperature record. We recognize that Greenland $\delta^{18} \mathrm{O}$ ice-core records, though stated to be a measure of annual mean temperature and used as such in this experiment, may actually be dominated by a winter temperature signal (Vinther et al., 2010).

In those cases where there exist multiple versions of a proxy record from the same site (e.g., the Torneträsk tree-ring record) the latest published version has been used. Whenever possible, preference was given to the highest resolution record available. If a tree-ring record exists both as a chronology of tree-ring widths and MXD we used the MXD record since this measure has stronger correlations to temperature (Briffa et al., 2002; D'Arrigo et al., 2009) and is generally reported as an integration of the whole growing season, whereas tree-ring width records primarily reflect conditions in the warmest months of the growing season (Tuovinen et al., 2009; Wilson et al., 2007).

\section{A2 Centennial variability and normalization of proxy records}

The proxies' observational sampling rates vary from annual to a minimum of two observations per century. Prior to fitting a 167-yr interpolative cubic smoothing spline, a frequency response equivalent to that of a 100 -yr moving average, those proxies with other than annual resolution are converted to an annually resolved, time-series using simple linear interpolation. Once annually resolved the spline is fit to the interpolated data and every 25th spline value from the year $850 \mathrm{AD}$ to $1950 \mathrm{AD}$ is retained. These 45 spline values become a new time-series representing the average centennial temperature variability as expressed by the proxy. The 45 spline values are further normalized by their mean and standard deviation over a base period defined as the 11th to the 19th centuries (i.e., the mean and standard deviation for the 33 spline values at the time points $1050 \mathrm{AD}, 1075 \mathrm{AD}, \ldots, 1850 \mathrm{AD})$. Twelve of the 45 centennial mean anomalies, those at the time points $850 \mathrm{AD}, 950 \mathrm{AD}, \ldots, 1950 \mathrm{AD}$, representing the 9th to 20th centuries, are the centennial mean anomalies presented in the many maps throughout this experiment. Two examples that illustrate the pre-processing procedure are given in Figs. S1 and S2. 
Table A1. All proxy records used in this study listed in geographical order from north to south.

\begin{tabular}{|c|c|c|c|c|c|c|}
\hline Name & Longitude & Latitude & Type & Resolution & Season $^{\mathrm{a}}$ & Reference \\
\hline 1. Lake C2 & -77.54 & 82.47 & Lake sediments & Annual & S & Lamoureux and Bradley (1996) \\
\hline 2. Lower Murray Lake & -69.32 & 81.21 & Lake sediments & Annual & S & Cook et al. (2009) \\
\hline 3. Severnaja & 106 & 81 & Lake sediments & Multi-decadal & S & Solomina and Alverson $(2004)^{b}$ \\
\hline 4. Lomonosovfonna & 17.42 & 78.85 & Ice-cores & Sub-decadal & $\mathrm{W}$ & Divine et al. (2011) \\
\hline 5. Devon Island & -82.5 & 75.33 & Ice-cores & Sub-decadal & A & Fisher et al. (1983) \\
\hline 6. NorthGRIP & -42.32 & 75.1 & Ice-cores & Decadal & A & NGRIP members (2004) \\
\hline 7. GISP2 & -38.5 & 72.6 & Ice-cores & Annual & A & Grootes and Stuiver (1997) \\
\hline 8. GISP2 & -38.5 & 72.6 & Other & Annual & A & Kobashi et al. (2010) \\
\hline 9. GRIP & -37.38 & 72.35 & Ice-cores & Annual & A & Vinther et al. (2010) \\
\hline 10. Crête & -37.32 & 71.12 & Ice-cores & Annual & A & Vinther et al. (2010) \\
\hline 11. Renland & 26.7 & 71.3 & Ice-cores & Annual & A & Vinther et al. (2008) \\
\hline 12. Indigirka & 148.15 & 70.53 & Tree-rings & Annual & S & Solomina and Alverson $(2004)^{b}$ \\
\hline 13. Avam-Taimyr & 93.00 & 70.00 & Tree-rings & Annual & S & Briffa et al. (2008) \\
\hline 14. Big Round Lake & -68.50 & 69.83 & Lake sediments & Annual & S & Thomas and Briner (2009) \\
\hline 15. Finnish Lapland & 25.00 & 69.00 & Tree-rings & Annual & S & Helama et al. (2010) \\
\hline 16. Laanila & 27.30 & 68.50 & Tree-rings & Annual & S & Lindholm et al. (2011) \\
\hline 17. Torneträsk & 19.80 & 68.31 & Tree-rings & Annual & S & Grudd (2008) \\
\hline 18. Nansen Fjord & -29.60 & 68.25 & Sea sediments & Multi-decadal & $\mathrm{S}$ & Jennings and Weiner $(1996)^{b}$ \\
\hline 19. Blue Lake & -150.46 & 68.08 & Lake sediments & Annual & S & Bird et al. (2009) \\
\hline 20. FM3 & 15.38 & 67.26 & Speleothems & Multi-decadal & A & Linge et al. (2009) \\
\hline 21. Lake SFL4 & -50.17 & 67.05 & Lake sediments & Sub-decadal & S & Willemse and Tornqvist (1999) \\
\hline 22. Braya Sø & -50.42 & 67.00 & Lake sediments & Multi-decadal & S & D'Andrea et al. (2011) \\
\hline 23. Yamal Penninsula & 69.00 & 67.00 & Other & Multi-decadal & S & Solomina and Alverson $(2004)^{b}$ \\
\hline 24. Core MD95-2011 & 7.64 & 66.97 & Sea sediments & Multi-decadal & S & Andersson et al. (2010) \\
\hline 25. Yamal & 69.17 & 66.92 & Tree-rings & Annual & S & Briffa (2000) \\
\hline 26. Polar Urals & 65.75 & 66.83 & Tree-rings & Annual & S & Esper et al. (2002a) \\
\hline 27. Donard Lake & -61.35 & 66.66 & Lake sediments & Annual & S & Moore et al. (2001) \\
\hline 28. North Iceland Shelf & -17.22 & 66.33 & Sea sediments & Multi-decadal & W & Jiang et al. (2005) \\
\hline 29. North Iceland Shelf & -17.22 & 66.33 & Sea sediments & Multi-decadal & S & Jiang et al. (2005) \\
\hline 30. Søylegrotta & 13.55 & 66.33 & Speleothems & Multi-decadal & A & Lauritzen and Lundberg (1999) \\
\hline 31. MD99-2275 & -19.30 & 66.30 & Sea sediments & Sub-decadal & $S$ & Ran et al. (2011) \\
\hline 32. MD99-2275_45 & -19.30 & 66.30 & Sea sediments & Sub-decadal & S & Sicre et al. (2011) \\
\hline 33. SG95 & 13.55 & 66.33 & Speleothems & Multi-decadal & A & Linge et al. (2009) \\
\hline 34. Dye-3 & -43.49 & 65.11 & Ice-core & Annual & A & Vinther et al. (2010) \\
\hline 35. Haukdalsvatn & -21.37 & 65.03 & Lake sediments & Sub-decadal & S & Geirsdóttir et al. (2009) \\
\hline 36. Iceland & -18.00 & 65.00 & Documentary & Multi-decadal & A & Bergthorsson (1969) ${ }^{\mathrm{b}}$ \\
\hline 37. Korallgrottan & 14.16 & 64.89 & Speleothems & Multi-decadal & A & Sundqvist et al. (2010) \\
\hline 38. Jämtland & 13.30 & 63.10 & Tree-rings & Annual & $S$ & Linderholm and Gunnarson (2005) \\
\hline 39. Lake Lehmilampi & 29 & 63 & Lake sediments & Annual & A & Haltia-Hovi et al. (2007) \\
\hline 40. Farewell Lake & -153.63 & 62.55 & Lake sediments & Multi-decadal & S & Hu et al. (2001) \\
\hline 41. Lake Korttajärvi & 25.68 & 62.33 & Lake sediments & Annual & A & Tiljander et al. (2006) \\
\hline 42. Hallet Lake & -146.20 & 61.50 & Lake sediments & Sub-decadal & S & McKay et al. (2008) \\
\hline 43. Moose Lake & -143.61 & 61.37 & Lake sediments & Multi-decadal & S & Clegg et al. (2010) \\
\hline 44. Lake Nautajärvi & 24.68 & 61.80 & Lake sediments & Annual & A & Ojala and Alenius (2005) \\
\hline 45. Iceberg Lake & -142.95 & 60.78 & Lake sediments & Annual & S & Loso (2009) \\
\hline 46. Outer Igaliku Fjord & -46.00 & 60.40 & Sea sediments & Multi-decadal & S & Jensen et al. $(2004)^{b}$ \\
\hline 47. Inner Igaliku Fjord & -46.00 & 60.40 & Sea sediments & Multi-decadal & $S$ & Jensen et al. $(2004)^{b}$ \\
\hline 48. Gulf of Alaska & -145 & 60 & Tree-rings & Annual & S & D'Arrigo et al. (2006) \\
\hline 49. Polovetsko-Kupanskoye & 38.7 & 56.94 & Pollen & Multi-decadal & A & Klimanov et al. (1995) \\
\hline 50. Usvyatskii Mokh & 32 & 56 & Pollen & Multi-decadal & A & Klimenko et al. (2001) \\
\hline 51. Russian Plains & 45.00 & 45.00 & Other & Decadal & A & Klimenko and Sleptsov (2003) \\
\hline 52. Columbia Icefield & -117.15 & 52.15 & Tree-rings & Annual & S & Luckman and Wilson (2005) \\
\hline 53. Columbia Icefield & -117.15 & 52.15 & Other & Annual & $\mathrm{W}$ & Edwards et al. (2008) \\
\hline 54. DeBilt winter & 5.18 & 52.1 & Documentary & Multi-decadal & $\mathrm{W}$ & van Engelen et al. $(2001)^{b}$ \\
\hline 55. DeBilt winter & 5.18 & 52.1 & Documentary & Multi-decadal & S & van Engelen et al. $(2001)^{b}$ \\
\hline 56. Central England & 1.00 & 52.00 & Documentary & Multi-decadal & A & Lamb (1965) \\
\hline 57. Teletskoe Lake & 87.61 & 51.76 & Lake sediments & Annual & A & Kalugin et al. (2009) \\
\hline 58. Sol Dav & 98.93 & 48.3 & Tree-rings & Annual & S & D'Arrigo et al. (2001) \\
\hline 59. Nadas Lake & 19.7 & 47.99 & Pollen & Multi-decadal & A & Sümegi et al. (2009) ${ }^{\mathrm{b}}$ \\
\hline 60. Eastern Carpathians & 25.10 & 47.20 & Tree-rings & Annual & S & Popa and Kern (2009) \\
\hline
\end{tabular}


Table A1. Continued.

\begin{tabular}{|c|c|c|c|c|c|c|}
\hline Name & Longitude & Latitude & Type & Resolution & Season $^{\mathrm{a}}$ & Reference \\
\hline 61. Oberer Landschitzsee & 13.36 & 47.13 & Lake sediments & Multi-decadal & S & Schmidt et al. (2007) \\
\hline 62. Spannagel Cave & 11.4 & 47.05 & Speleothems & Sub-decadal & A & Mangini et al. (2005) \\
\hline 63. Lake Neuchatel & 6.7 & 46.8 & Pollen & Multi-decadal & A & Filippi et al. $(1999)^{b}$ \\
\hline 64. The Alps & 8.00 & 46.30 & Tree-rings & Annual & $\mathrm{S}$ & Büntgen et al. (2006) \\
\hline 65. Conroy Lake & -67.88 & 46.28 & Pollen & Multi-decadal & S & Gajewski (1988) \\
\hline 66. Marion Lake & -89.09 & 46.26 & Pollen & Multi-decadal & S & Bernabo (1981) \\
\hline 67. Hells Kitchen Lake & -89.42 & 46.11 & Pollen & Multi-decadal & S & Gajewski (1988) \\
\hline 68. Central Europe & 8.00 & 46.00 & Tree-rings & Annual & S & Büntgen et al. (2011) \\
\hline 69. French Alps & 9.00 & 46.00 & Tree-rings & Annual & S & Corona et al. (2011) \\
\hline 70. Grotta Savi & 13.89 & 45.62 & Speleothems & Decadal & A & Frisia et al. (2005) \\
\hline 71. Lake Anterne & 6.47 & 45.59 & Lake sediments & Multi-decadal & $\mathrm{S}$ & Millet et al. (2009) \\
\hline 72. Emerald Basin & -62.00 & 45.00 & Sea sediments & Multi-decadal & A & Keigwin et al. (2003) \\
\hline 73. Basin Pond & -70.03 & 44.28 & Pollen & Multi-decadal & $\mathrm{S}$ & Gajewski (1988) \\
\hline 74. Lake of the Clouds & -71.25 & 44.25 & Pollen & Multi-decadal & S & Gajewski (1988) \\
\hline 75. Les Merveilles & 7.45 & 44.03 & Tree-rings & Annual & S & $\left(_{\text {ITRDB FRAN010) }}{ }^{\mathrm{c}}\right.$ \\
\hline 76. Idaho & -114.00 & 44.00 & Tree-rings & Annual & S & $\left(\right.$ ITRDB ID009, ID010, and ID012) ${ }^{\mathrm{c}}$ \\
\hline 77. Clear Pond & -74.01 & 43.45 & Pollen & Multi-decadal & $\mathrm{S}$ & Gajewski (1988) \\
\hline 78. Penido Vello & -7.34 & 43.32 & Other & Multi-decadal & A & Martínez-Cortizas et al. (1999) \\
\hline 79. Northern Spain & -3.50 & 42.90 & Speleothems & Multi-decadal & A & Martín-Chivelet et al. (2011) \\
\hline 80. Jones Lake & -84.56 & 42.77 & Pollen & Multi-decadal & $\mathrm{S}$ & Bernabo $(1981)^{\mathrm{b}}$ \\
\hline 81. Lake 27 & -83.43 & 42.73 & Pollen & Multi-decadal & $\mathrm{S}$ & Bernabo $(1981)^{b}$ \\
\hline 82. Lake Redon & 0.77 & 42.64 & Lake sediments & Multi-decadal & $\mathrm{W}$ & Pla and Catalan (2005) \\
\hline 83. Jinchuan & 126.37 & 42.33 & Lake sediments & Multi-decadal & A & Hong et al. (2000) \\
\hline 84. Hani & 126.51 & 42.21 & Lake sediments & Multi-decadal & A & Hong et al. $(2009)^{b}$ \\
\hline 85. Daihai Basin & 112.68 & 40.57 & Lake sediments & Multi-decadal & S & Xu et al. (2003) \\
\hline 86. Tien Shan & 72.00 & 40.00 & Tree-rings & Annual & $\mathrm{S}$ & Esper et al. $(2003)^{b}$ \\
\hline 87. Gulf of Taranto & 17.88 & 39.75 & Sea sediments & Multi-decadal & A & Taricco et al. (2009) \\
\hline 88. ShiHua Cave & 115.56 & 39.47 & Speleothems & Annual & $\mathrm{S}$ & Tan et al. (2003) \\
\hline 89. Chesapeake Bay & -76.40 & 39.00 & Sea sediments & Multi-decadal & S & Cronin et al. (2003) \\
\hline 90. Hill 10842 & -114.23 & 38.93 & Tree-rings & Annual & S & $\left(\right.$ ITRDB NV516) ${ }^{\mathrm{c}}$ \\
\hline 91. Sugan Lake & 93.9 & 38.85 & Lake sediments & Multi-decadal & $\mathrm{W}$ & Qiang et al. (2005) \\
\hline 92. Dunde & 96.40 & 38.10 & Ice-cores & Decadal & A & Thompson et al. (2006) \\
\hline 93. Lucky Horseshoe & -118.33 & 37.87 & Tree-rings & Annual & $\mathrm{S}$ & $\left(\right.$ ITRDB NV519) $^{\mathrm{c}}$ \\
\hline 94. Glass Mountain & -118.68 & 37.75 & Tree-rings & Annual & S & $\left(\right.$ ITRDB CA633) ${ }^{\mathrm{c}}$ \\
\hline 95. Sheep Mountain & -118.22 & 37.37 & Tree-rings & Annual & S & $\left(\right.$ ITRDB CA534) ${ }^{\mathrm{c}}$ \\
\hline 96. M40-4-SL78 & 13.19 & 37.03 & Sea sediments & Multi-decadal & A & Emeis and Dawson (2003) \\
\hline 97. Korea & 128.00 & 37 & Pollen & Multi-decadal & A & Park et al. $(2011)^{\mathrm{b}}$ \\
\hline 98. Lake Qinghai & 100 & 37 & Lake sediments & Multi-decadal & A & Liu et al. (2006) \\
\hline 99. Southern Sierra Nevada & -118.90 & 36.90 & Tree-rings & Annual & S & Graumlich (1993) \\
\hline 100. Tibet & 98.5 & 36.5 & Tree-rings & Annual & A & Liu et al. (2009) \\
\hline 101. Karakorum Mountains & 74.99 & 36.37 & Other & Annual & A & Treydte et al. (2009) \\
\hline 102. Upper Wright Lakes & -118.22 & 36.37 & Tree-rings & Annual & $\mathrm{S}$ & Lloyd and Graumlich (1997) \\
\hline 103. Boreal Plateau & -118.33 & 36.27 & Tree-rings & Annual & S & Lloyd and Graumlich (1997) \\
\hline 104. Dulan & 98 & 36 & Tree-rings & Annual & A & Zhang et al. (2003) \\
\hline 105. Guliya & 81.48 & 35.28 & Ice-cores & Decadal & A & Thompson et al. (2006) \\
\hline 106. Southern Colorado Plateau & -111.4 & 35.2 & Tree-rings & Annual & $\mathrm{S}$ & Salzer and Kipfmueller (2005) \\
\hline 107. East China & 114 & 35 & Documentary & Multi-decadal & $\mathrm{W}$ & Ge et al. (2003) \\
\hline 108. Karakorum Mountains & 76 & 35 & Tree-rings & Annual & A & Esper et al. (2002b) \\
\hline 109. Bermuda & -57.63 & 33.72 & Sea sediments & Multi-decadal & A & Keigwin (1996) \\
\hline 110. Western Himalaya & 76.45 & 32.50 & Tree-rings & Annual & $\mathrm{S}$ & Yadav et al. $(2011)^{\mathrm{b}}$ \\
\hline 111. Yangtze Delta & 121.0 & 32.0 & Documentary & Decadal & A & Zhang et al. $(2008)^{b}$ \\
\hline 112. Yakushima Island & 130.3 & 30.2 & Other & Multi-decadal & A & Kitagawa and Matsumoto (1995) \\
\hline 113. Pigmy Basin & -91.42 & 27.2 & Sea sediments & Multi-decadal & A & Richey et al. (2007) \\
\hline 114. Jiaming Lake & 121.3 & 25.01 & Lake sediments & Multi-decadal & A & Lou and Chen (1997) \\
\hline 115. SO90-39KG & 65.92 & 24.83 & Sea sediments & Multi-decadal & A & Doose-Rolinski et al. (2001) \\
\hline 116. Pescadero Basin & -108.2 & 24.27 & Sea sediments & Multi-decadal & A & Barron and Bukry (2007) \\
\hline 117. Great Ghost Lake & 120.51 & 22.52 & Lake sediments & Multi-decadal & A & Lou and Chen (1997) \\
\hline 118. Caribbean Sea & -66.6 & 17.88 & Sea sediments & Multi-decadal & A & Nyberg, et al. (2002) \\
\hline 119. Cariaco Basin & -64.56 & 10.42 & Sea sediments & Multi-decadal & A & Goni et al. (2004); Black et al. (2007) \\
\hline 120. Indo-Pacific Warm Pool & 119.27 & -3.53 & Sea sediments & Sub-decadal & A & Oppo et al. (2009) \\
\hline
\end{tabular}

${ }^{\mathrm{a}} \mathrm{A}=$ Annual, $\mathrm{S}=$ Summer, $\mathrm{W}=$ Winter. Proxy records marked with ${ }^{\mathrm{b}}$ were digitized from publish figures. ${ }^{\mathrm{c}}$ ITRDB $=$ The International Tree-Ring Data Bank at the NOAA Paleoclimatology Programme and World Data Center for Paleoclimatology (http://www.ncdc.noaa.gov/paleo/treering.html). 

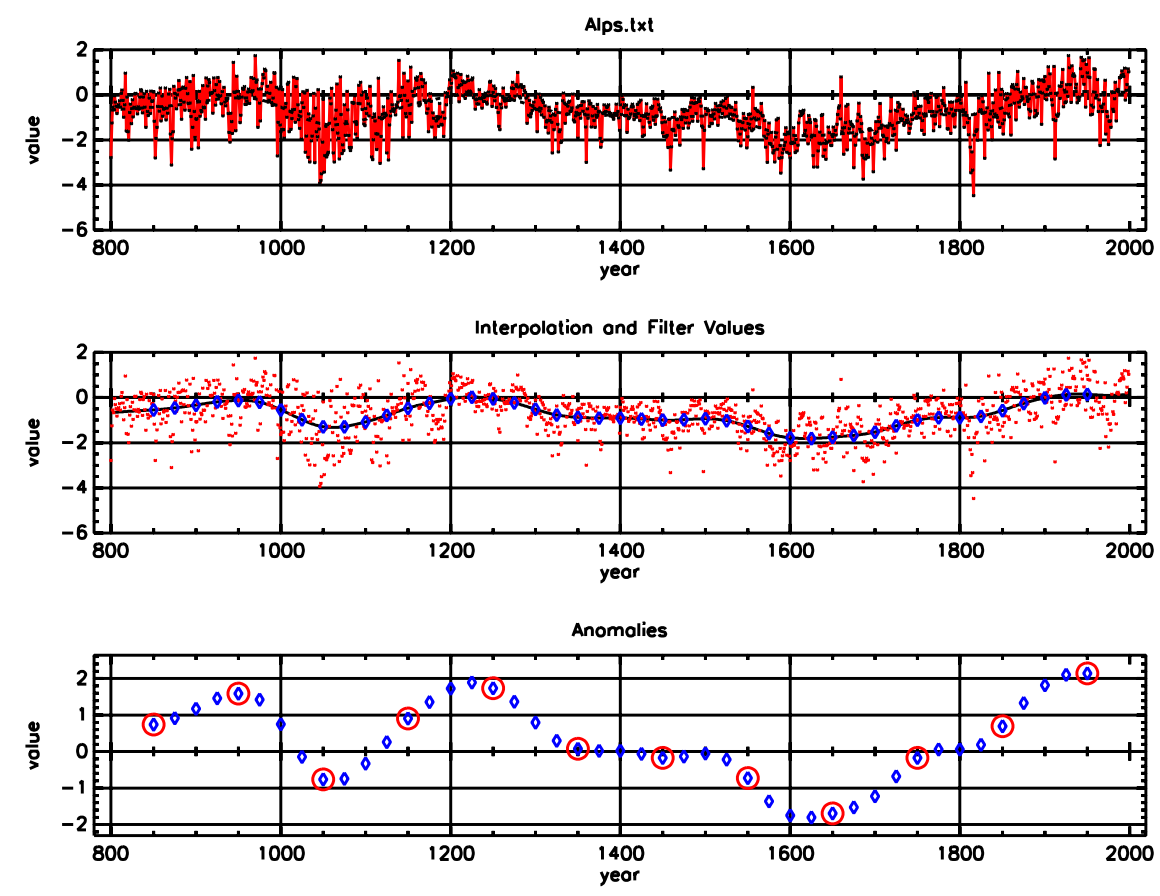

Fig. A1. Example illustrating the transformation of an annually resolved proxy record to a centennially resolved anomaly time series. The top panel shows the raw data, in original units, with its spline fit. The middle panel shows the raw data (red dots) and the $45,100 \mathrm{yr}$, moving averages (overlap $=25 \mathrm{yr}$ ) between $850 \mathrm{AD}$ and $1950 \mathrm{AD}$ (blue diamonds). The bottom panel shows the 45, normalized (base period: 11 th19th centuries) centennial filter values (blue diamonds) and the values of the 12 common centuries (red circles).
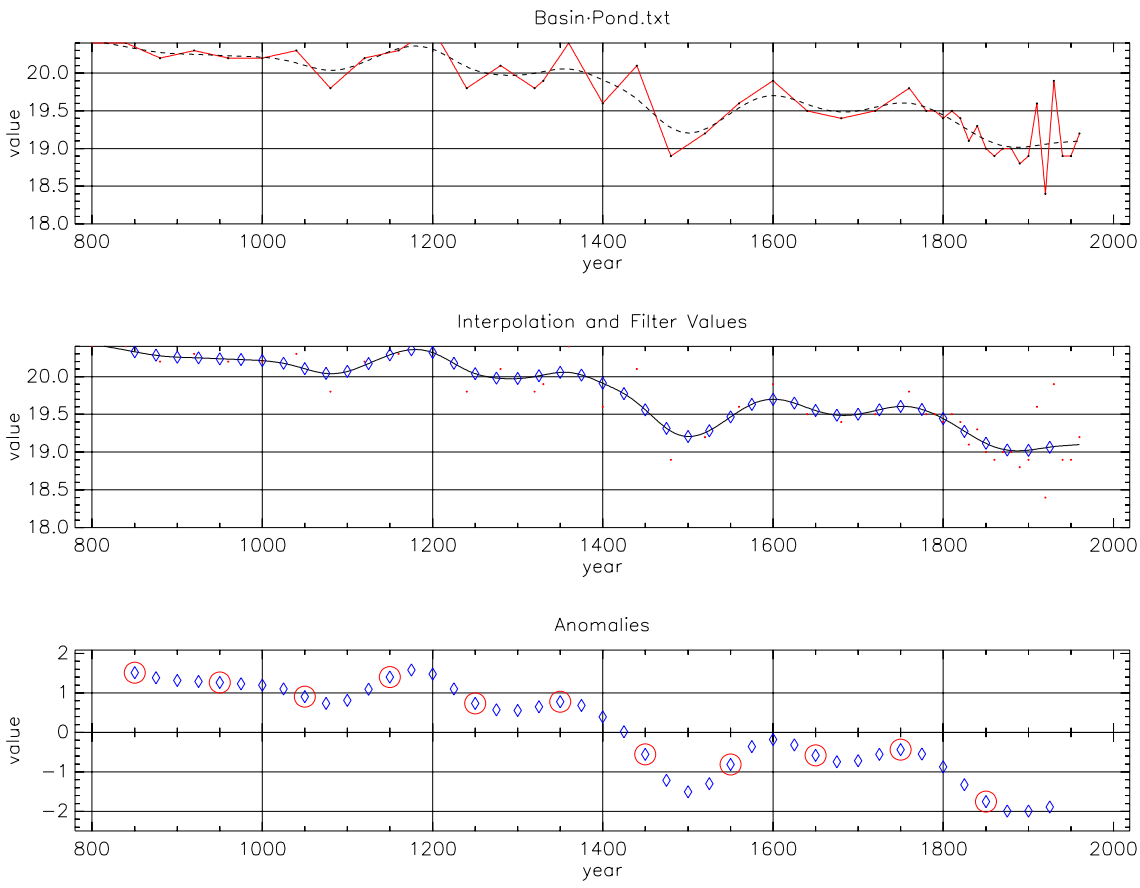

Fig. A2. An example illustrating the transformation of a non-annually resolved proxy record to a centennially resolved anomaly series. The top panel shows the raw data, in original units, with its spline fit. The middle panel shows the raw data (red dots) and the $45,100 \mathrm{yr}$, moving averages (overlap $=25 \mathrm{yr}$ ) between $850 \mathrm{AD}$ and $1850 \mathrm{AD}$ (blue diamonds). The bottom panel shows the 45, normalized (base period: 11 th19 th centuries) centennial filter values (blue diamonds) and the values of the 12 common centuries (red circles). 


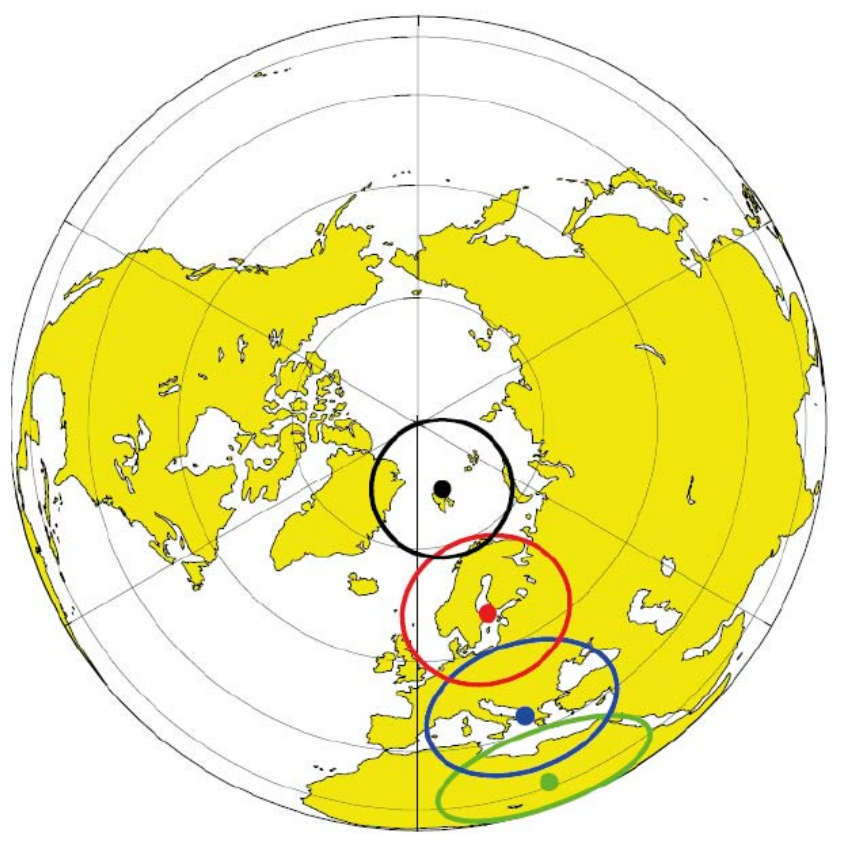

Fig. A3. Example of search circles used for sign tests, spatial averaging and gridding placed along $20^{\circ} \mathrm{E}$. Their radii decrease linearly with latitude from $2000 \mathrm{~km}$ at the equator to $1000 \mathrm{~km}$ at the pole. The four circles illustrated are placed at $20^{\circ}, 40^{\circ}, 60^{\circ}$ and $80^{\circ} \mathrm{N}$ and have radial distances of $1778 \mathrm{~km}, 1556 \mathrm{~km}, 1333 \mathrm{~km}$ and $1111 \mathrm{~km}$, respectively. The apparently elliptic shape of the circles is a consequence of the map projection.

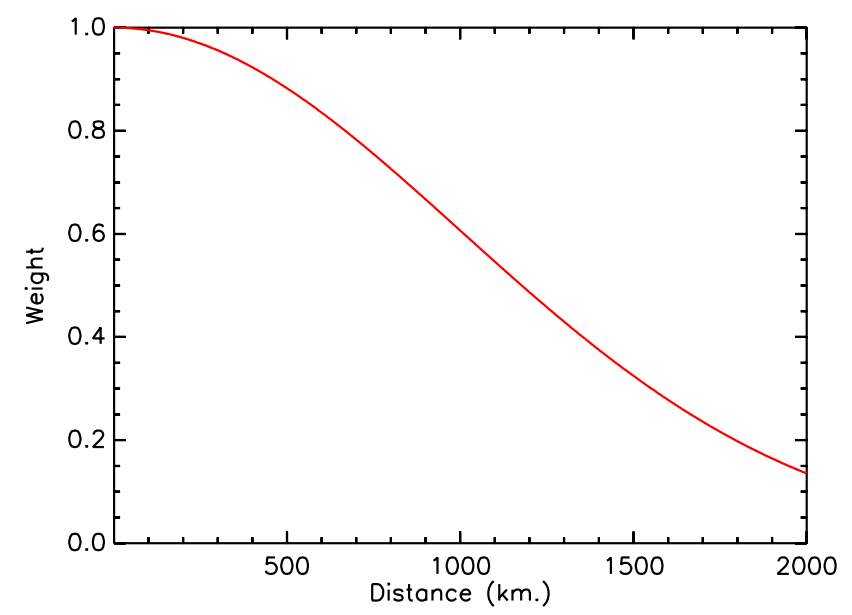

Fig. A4. The Gaussian weight function for proxies located at a distance of $x \mathrm{~km}$ from a grid node, as derived from Eq. (A3), for an example search radius $(R)$ of $2000 \mathrm{~km}$.

\section{A3 Correlation decay length of centennial temperature variability and anisotropic search radii}

In order to find an appropriate search distance for the spatial averaging, the sign test and producing maps of gridded anomalies we need to consider the correlation decay structure of centennial temperatures and the spatial density of the

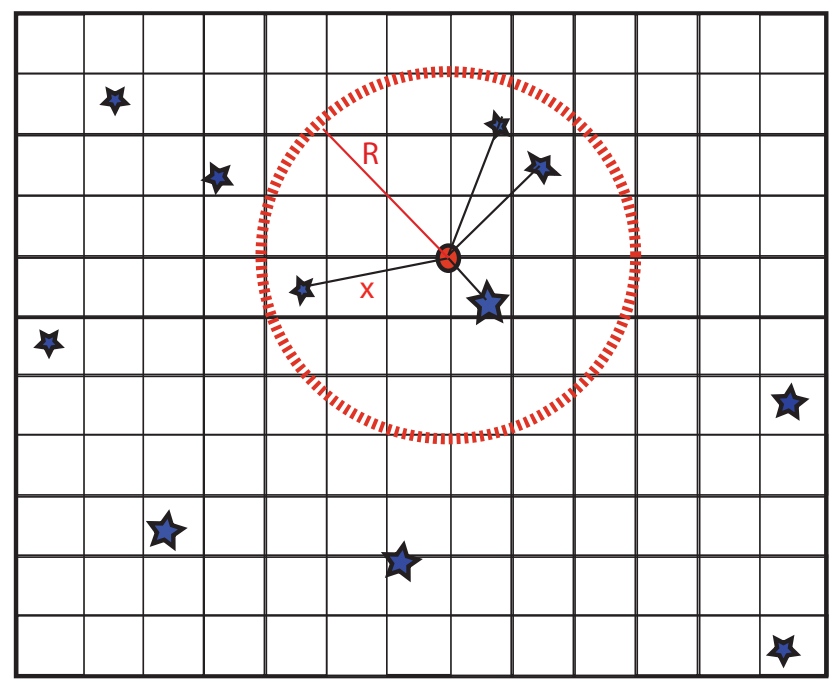

Fig. A5. Spatial gridding of centennial proxy anomalies on a $1^{\circ} \times 1^{\circ}$ grid using a modified near-neighbour gridding algorithm. Capital $R$ is the search radius from each grid node as computed by Eq. (A2) where lat is the latitude of the grid node. Lower case $x$ is the great circle distance from the grid node to a proxy location. Provided there are 3 or more proxies within search distance $R$ the grid node value is computed as the weighted average of the proxies centennial mean anomalies using weights defined by Eq. (A3).

available proxy dataset. The correlation of temperature variability at different locations on the Earth's surface typically decreases with increasing distance between locations. This correlation decay may be expressed as a negative exponential equation of the form

$r=e^{-x / x_{0}}$

Here, $r$ is the correlation between temperature variations at distinct locations, $x$ is the distance between the locations, and $x_{0}$ is the characteristic correlation decay length (CDL). The rate at which the correlation decay takes place is dependent on the time scale of the variations; the correlation decays slower for longer than for shorter time-scales. The CDL also varies geographically and between seasons (Jones et al., 1997).

For the current study it is useful to have some knowledge about the CDL of centennial temperature variability because this helps determine the size of geographic regions/areas within which climate can be assumed to behave similarly. If the proxies within a CDL-defined region contain a meaningful temperature signal one would expect, when it was anomalously cold (or warm), the majority of within-area proxies will respond similarly. Therefore, the mean temperature anomaly, calculated from all proxies within the CDLregion, should be a fair estimate of central tendency for that region.

The CDL-region should be small enough to ensure that the real centennial temperature (within-area) variability is 

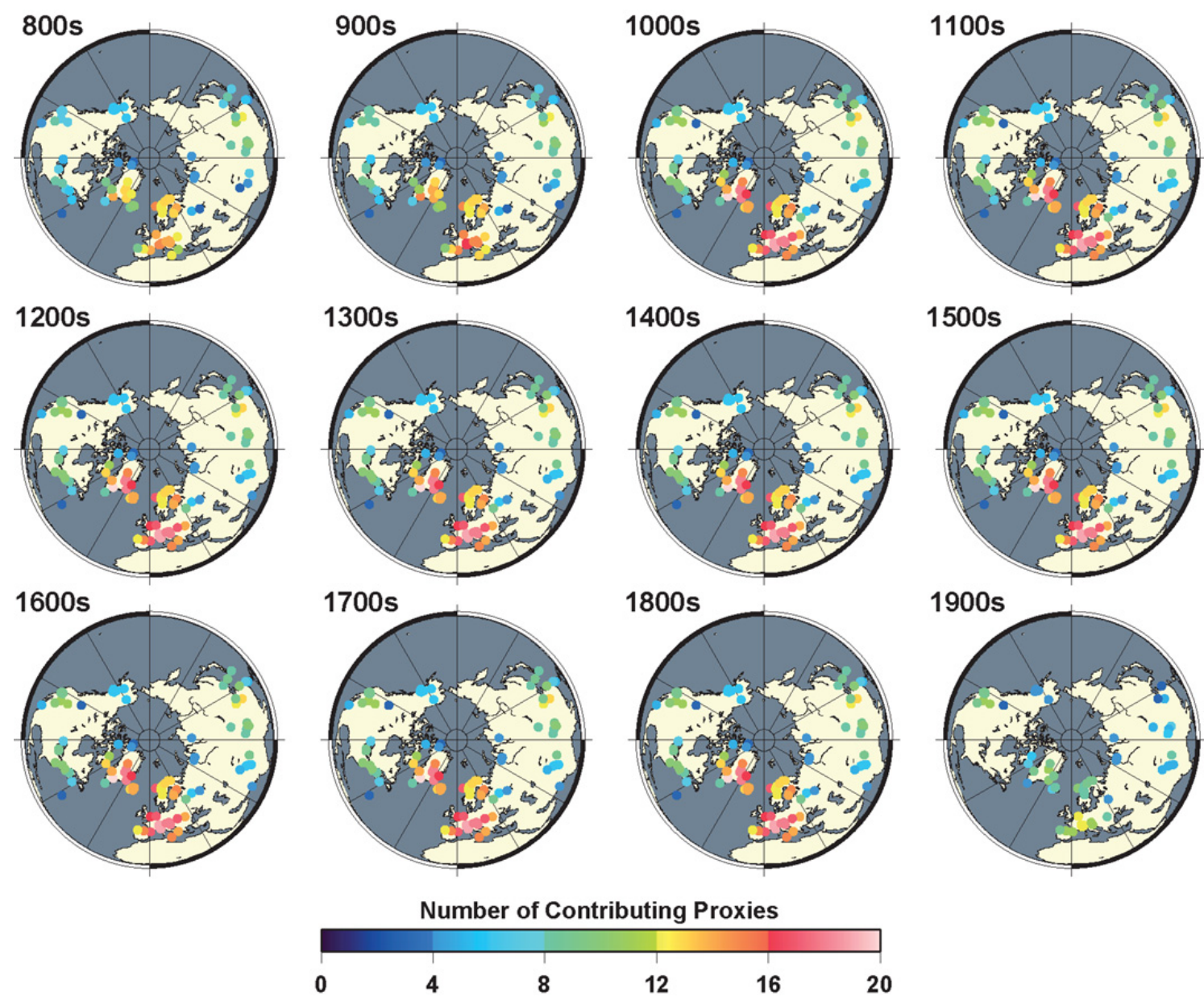

Fig. A6. Number of contributing proxies considered in each proxy-centred anisotropic weighted mean calculation where there are 3 or more neighbouring proxies found in the search radius.

preserved and large enough to capture a sufficiently large number of proxies for calculating meaningful areal averages. However, the regions should not be so large that spatial details of temperature variability across the hemisphere cannot be distinguished. Hence, the determination of the size of the region must be based on a judgment that takes into account both the spatial distribution and density of the available proxies and some knowledge about the correlation decay structure for centennial temperature variations.

Unfortunately the CDL for centennial mean temperatures is not well known, as it cannot be estimated directly from the comparatively short instrumental record. Hence, climate model simulations are needed to help obtain some estimates. Jones et al. (1997) studied global patterns of the CDL from both an instrumental observational dataset and in three climate model simulations at inter-annual and decadal time-scales. They also analysed the CDL on centennial time-scales from one model simulation. Their study reveals that the CDL for internal variability, seen in control simulations, is typically shorter than that seen for externally forced simulations and shorter than in the instrumental observations - which must be assumed to contain a certain amount of externally forced variability. Different climate models provide different CDL values. Hence it is not possible to uniquely determine the structure of CDL for centennial temperature variations directly. However, Table 1 in Jones et al. (1997) suggests that the global mean value of CDL for unforced decadal variability, based on the two models that apparently produced the most realistic results, is on the order of $\sim 2000 \mathrm{~km}$ for annual mean temperatures and $\sim 1500 \mathrm{~km}$ for summer temperatures (which is the season with the shortest CDL). Certainly, the global mean value of CDL for real centennial temperatures must be longer. Table 5 in Jones et al. (1997) suggests that it could be on the order of $\sim 75 \%$ longer than that for decadal temperatures. The CDL can also vary geographically and is typically longer at the equator than at the pole. An average CDL for centennial temperature variability of at least $\sim 2000$ to $\sim 1500 \mathrm{~km}$ is supported by the findings of Wirtz et al. (2010) who studied spatial patterns from 124 globally distributed climate proxy archives for the Holocene. 
To determine the size of regions within which centennial temperature variability can be expected to be rather strongly, positively, correlated, one should choose regions where the distance between the center and periphery, i.e., the search radius, is smaller than the CDL for centennial time-scales. Guided by the results in Jones et al. (1997) we conclude a flexible search radius of $2000 \mathrm{~km}$ at the equator, that is allowed to decrease linearly with latitude to $1000 \mathrm{~km}$ at the pole, is small enough to ensure that the mean centennial temperature variability at the search-centre should be positively correlated with most locations within the search radius. Such an anisotropic search function can be expressed mathematically as:

$R=\operatorname{lat} \times\left(\frac{r_{\text {min }}-r_{\text {max }}}{90}\right)+r_{\text {max }}$

Here, $R$ is the radius of a circle centred on any proxy or latitude lat. in the $\mathrm{NH}, r_{\min }$ is the radius of a circle centred on the North Pole, and $r_{\text {max }}$ is the radius of a circle centred on the equator (Fig. A3). Such circles, with $r_{\min }=1000$ and $r_{\max }=$ 2000 , are wide enough to capture a reasonably large number of proxies and small enough to ensure that large-scale spatial patterns in temperature variability can be distinguished and are thus used in our sign tests, spatial averaging and producing maps of gridded values as described below (note that if Eq. (A2) is used in the Southern Hemisphere, the latitude lat must be given with its absolute (positive) value).

The relative weight given to each proxy decreases from 1 at the grid node to $e^{-2} \approx 0.14$ at the search periphery (Fig. A4), following the Gaussian weight function:

weight $=e^{-2 x^{2} / R^{2}}$

Here, weight is the weight given to a proxy value located at distance $x$ from a grid or proxy node and $R$ is the radius of the search circle defined by (Eq. A2). The Gaussian weight function is chosen because the Gaussian filter is frequently used as a low-pass filter for noise suppression both in time-series analysis and image processing (Wessel and Smith, 1998). In our notation, the quantity $R / 2$ corresponds to what is usually referred to as the standard deviation or the scale. In our application the scale varies between $1000 \mathrm{~km}$ at the equator and $500 \mathrm{~km}$ at the pole. What is important is that the weights decay from large values at the grid node to small values at the search periphery. This is well achieved by Eq. (A3).

\section{A4 Anisotropic spatial smoothing}

The same search and weight functions are also used for calculating weighted means of neighbouring proxy anomalies where an anisotropic search is centred over the location of each proxy as opposed to the nodes of a Cartesian coordinate system. A weighted mean of centennial mean anomalies for a proxy location is performed if there are two or more neighbouring proxies (within the search distance) and all proxies, including the center proxy, possess a value for the century being considered. Thus, the minimum number of proxies contributing to any weighted-mean centennial anomaly is three. Using these criteria the maximum number of proxies contributing to a single weighted-mean centennial anomaly, given the length and spatial distribution of the data used in this experiment, is twenty (Fig. A6).

\section{A5 Anisotropic spatial gridding}

The gridding of proxy data over a polar projection of the $\mathrm{NH}$ is done using a modification of the near-neighbour algorithm. We employ an anisotropic search radius (Eq. A2) to compute the values at each node of a $1^{\circ} \times 1^{\circ}$ grid covering the hemisphere. Figure A5 illustrates the procedure; all centennial proxy anomaly values within the search radius from each grid node contribute to a weighted mean assigned to the node's location if there are two or more node-local proxies. The weights used are defined by Eq. (A3).

\section{Appendix B}

\section{The sign test - a simple robust anomaly test}

Figure 1B presents results of sign tests (Arbuthnott, 1710) showing the degree of spatial agreement, for each of the 12 centuries considered, of the signs of the anomalies among neighbouring proxies within an anisotropic search radius that decreases from $2000 \mathrm{~km}$ at the equator to $1000 \mathrm{~km}$ at the pole. The null hypothesis is that all the local proxy anomalies located within a given search circle, centred over each proxy, are equally likely to be positive as negative. If this hypothesis is true, then a strong majority in either direction is unlikely. Hence when such a majority is observed we reject the null hypothesis and conclude that the observed agreement between the proxy anomalies indicates the presence of a signal in this direction.

Using the significance level 5\% and a normal approximation one finds that the number of agreeing anomalies needed is $n / 2+\sqrt{ } n$, or to put it differently, the number of disagreeing anomalies can be at most $n / 2-\sqrt{ } n$. One of the assumptions underlying the sign test is that the observations are independent, which is difficult to verify in the present situation. For this reason the sign test should be viewed as a simple robust method for deciding which anomalies show reasonable agreement with their neighbours (Table B1).

The regional sign tests strengthen the overall impressions from Fig. 3, the widespread agreement of positive anomalies in the 10th century and negative anomalies in the 17th century. However, in the 20th century there is notably less widespread agreement on the sign of anomalies. In particular, proxies from land areas in and surrounding the North Atlantic region and western Asia do not agree that the last century, as a whole, was warmer than the 11th-19th century average. The lack of agreement on the sign in the 20th 
Table B1. The maximum number of permissible disagreeing proxies $(d)$ for a given number of total proxies $(n)$ found within a search radius to pass the sign test.

\begin{tabular}{rrrrrrrrrrrrrrrrrrr}
\hline$n$ & 3 & 4 & 5 & 6 & 7 & 8 & 9 & 10 & 11 & 12 & 13 & 14 & 15 & 16 & 17 & 18 & 19 & 20 \\
\hline$d$ & 0 & 0 & 0 & 1 & 1 & 1 & 2 & 2 & 2 & 3 & 3 & 3 & 4 & 4 & 4 & 5 & 5 & 6 \\
\hline
\end{tabular}
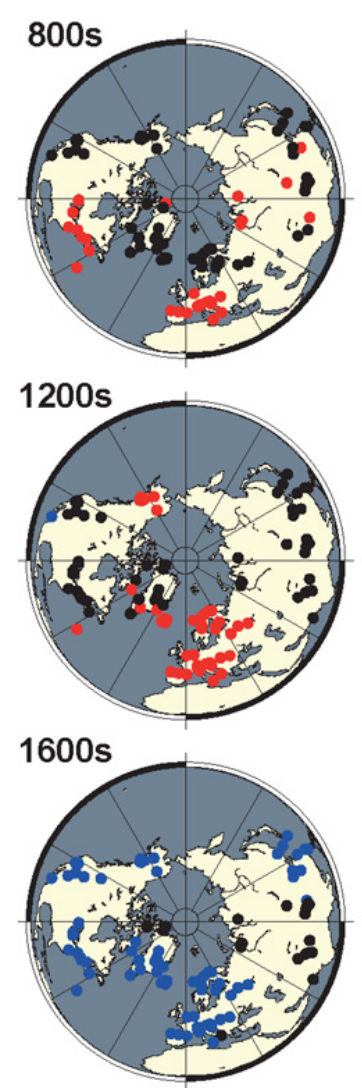
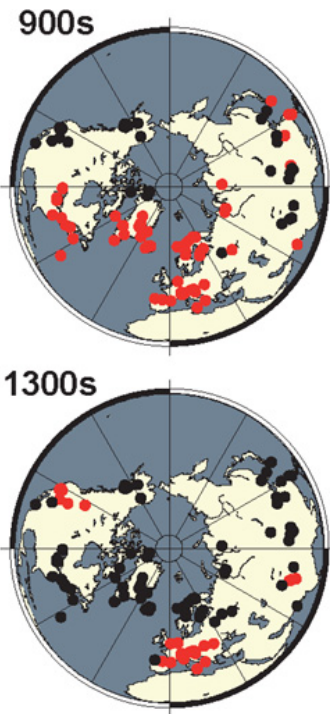

1700 s

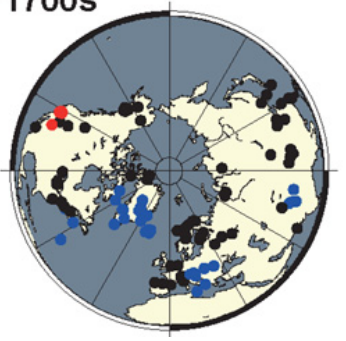

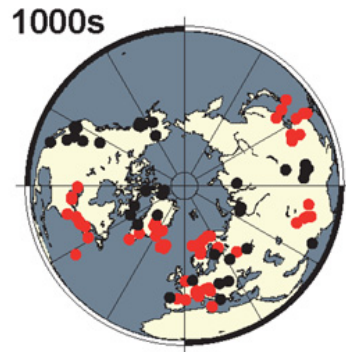

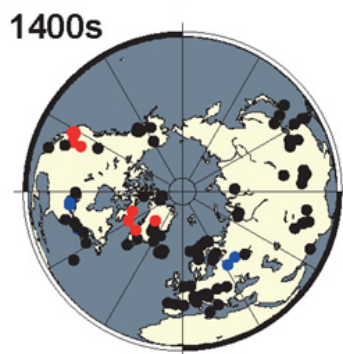

$1800 \mathrm{~s}$

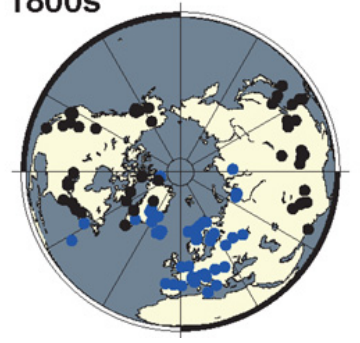

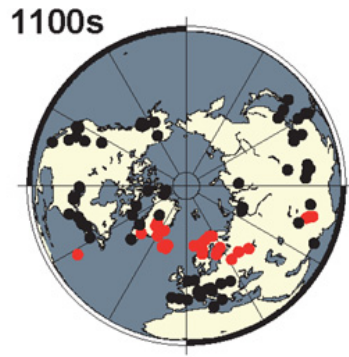

$1500 \mathrm{~s}$

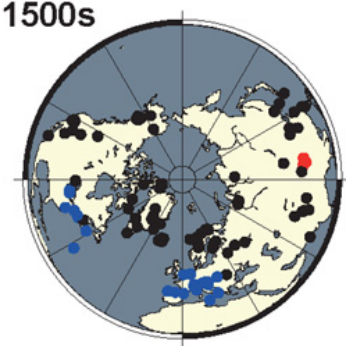

1900s

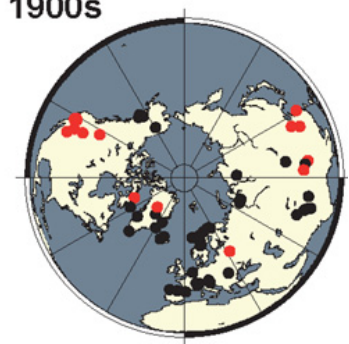

Fig. B1. Sign test of standardized centennial proxy anomalies. Red and blue dots indicate agreement within a search radius centered on each individual proxy location positive or negative, respectively. The search radii of the circles decrease linearly with latitude from $2000 \mathrm{~km}$ at the equator to $1000 \mathrm{~km}$ at the pole. Black dots indicate no significant agreement of the sign of anomalies.

century does not necessarily mean that the proxies fail to capture the thermal state of the climate in the last century: it could be that the proxy values are sufficiently close to the mean over the nine-century long baseline period for a substantial number of them to end up on either side of the baseline period mean. However, not all proxy records that are used for the 20th century analysis have data that completely cover the last $15 \mathrm{yr}$ (1985-1999 AD). This period is known to have been warmer than the mean of the last century (Fig. C1). If all the proxy records had data up to the end of the last century, more widespread agreement of positive anomalies would be expected.

\section{Appendix C}

\section{Spatial patterns of decadal mean temperatures in gridded instrumental observations}

To obtain a visual comparison between the spatio-temporal patterns of $\mathrm{NH}$ centennial temperatures seen in the proxy data for the last twelve centuries and the instrumentally observed $\mathrm{NH}$ temperatures we plot, in a similar manner as in Fig. 2, the decadal means of the $5^{\circ} \times 5^{\circ}$ grid box temperatures from the HadCRUT3 dataset (Brohan et al., 2006). Figure $\mathrm{C} 1$ shows, for each of the last twelve decades, the temperature anomalies (in ${ }^{\circ} \mathrm{C}$ ) for each grid box expressed as deviations from the 1900-1999 mean. Grid boxes located over ocean areas are masked for the sake of 

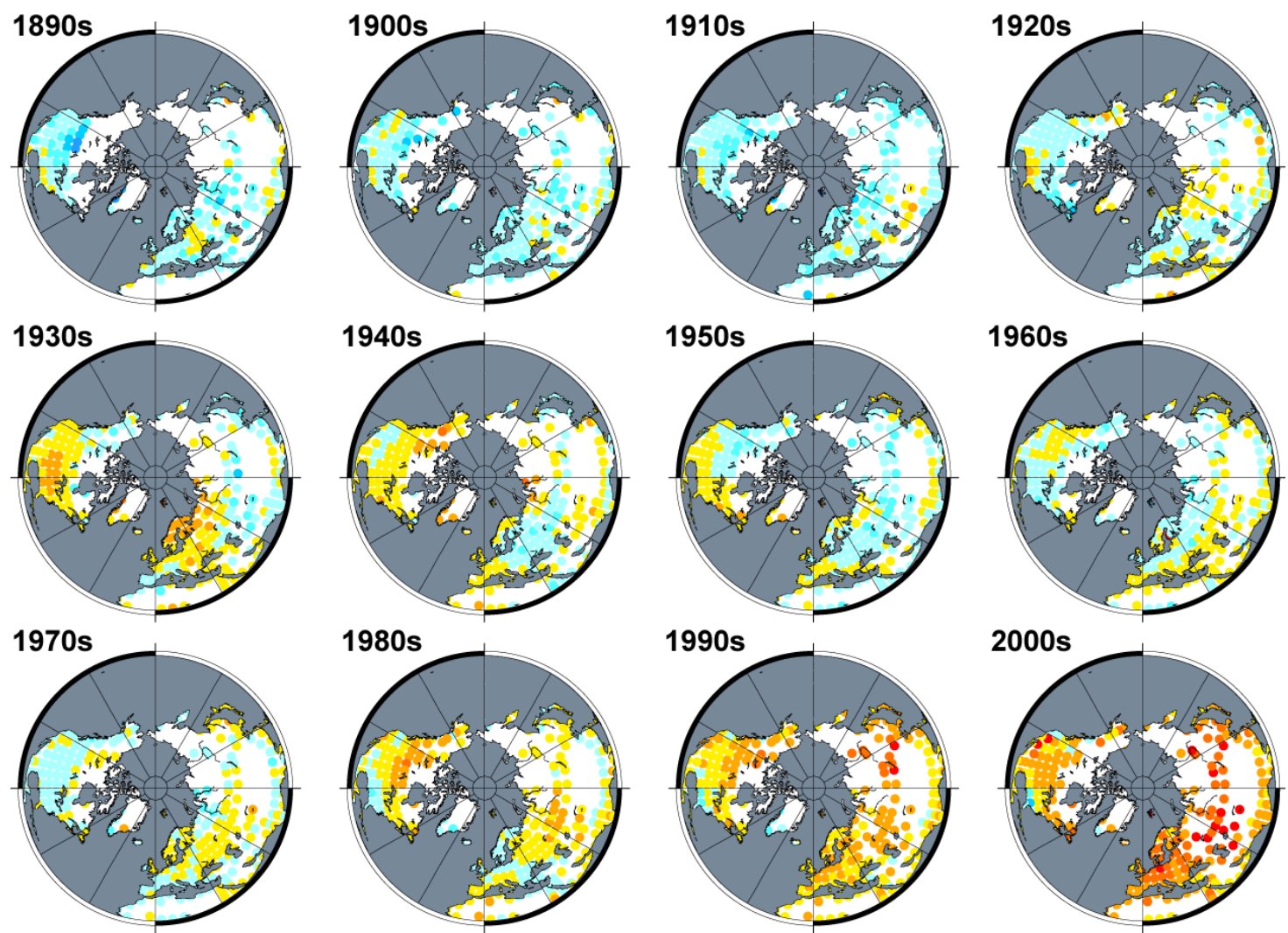

1980s

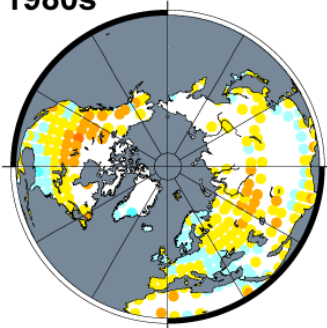

1990s

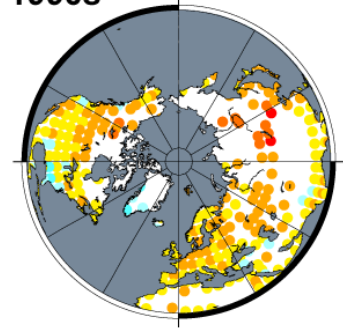

2000s

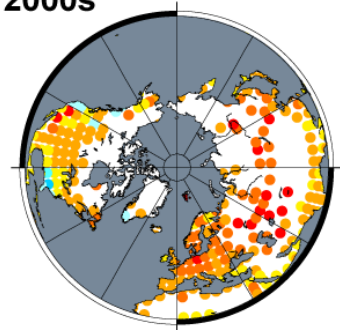

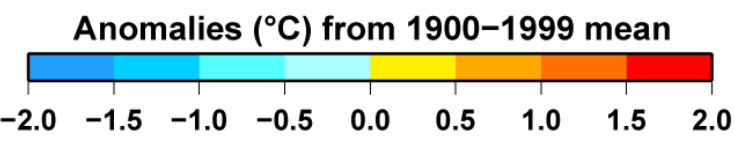

Fig. C1. Maps of decadal mean temperature anomalies (in ${ }^{\circ} \mathrm{C}$ ) from the $1900-1999$ mean, for all NH land grid boxes in the HadCRUT3 dataset (Brohan et al., 2006) having at least $80 \%$ complete monthly data. The labels 1890s and 1900s etc., denote the mean for the period 1890-1899 and 1900-1910 etc., grid boxes over ocean areas are masked.

comparison. The decadal deviation is calculated and plotted wherever a grid box has $80 \%$ or more monthly data in the period 1900-1999 and $80 \%$ or more monthly data in the decade in question.

A widespread NH warming since the late 19th century is clearly illustrated in the maps. The regions with sufficient data show that the 1890 s to 1910 s were colder than the 20th century mean and that the 1990s was the warmest decade in the last century. The first decade in the 21 st century was more than $1{ }^{\circ} \mathrm{C}$ above the 20th century mean. At a few locations temperatures in the last decade were colder than the century mean. These are located in southern Greenland and North America. A well-documented early warm period is seen in the 1930s and 1940s (Callendar, 1938; Delworth and Knutson, 2000; LiJuan et al., 2007; Tett et al., 2002), but the warmth in that period was not as geographically widespread as the post-1990 warmth (Brohan et al., 2006). The last decade (2000-2009) was the warmest observed decade in the $\mathrm{NH}$ land areas and also the decade with the most widespread warmth.
In Fig. $\mathrm{C} 1$ the spatial coherency of the instrumental decadal temperatures is clearly stronger than the proxy-based centennial temperature anomalies in Fig. 2. Because the spatial coherence is expected to increase with increasing timescales this comparison reveals that the proxy series exhibit a substantial amount of noise which motivates the use of spatial averaging of proxy anomalies. Figure $\mathrm{C} 1$ shows us that the areas with poor coverage of instrumental temperature observations are often the same areas as those where proxy data are lacking. Consequently, even if new proxy series are retrieved from areas currently devoid of proxy information, it will still be difficult to calibrate them.

\section{Supplementary material related to this article is available online at: http://www.clim-past.net/8/227/2012/ cp-8-227-2012-supplement.zip.}


Acknowledgements. We thank Anders Moberg for help with funding through grants from the Swedish Research Council (grants 70454201 and 90751501) and the European Union (FP6 grant 017008, "Millennium" project) and for valuable suggestions for method development and comments on earlier stages of the manuscript. Many thanks are due to Ed Cook and Håkan Grudd for their discussions and comments. We are thankful to all those researchers who have provided us with un-archived proxy data and especially thankful to the many scientists who have graciously contributed their data to the World Data Center for Paleoclimatology and similar public databases without which studies like this would not be possible. The publication of this article was jointly financed by the Bert Bolin Centre for Climate Research at Stockholm University and the Department of History at Stockholm University.

Edited by: J. Luterbacher

\section{References}

Akima, H.: A new method of interpolation and smooth curve fitting based on local procedures, J. Assoc. Comput. Mach., 17, 589602, 1970 .

Ammann, C. and Wahl, E.: The importance of the geophysical context in statistical evaluations of climate reconstruction procedures, Climatic Change, 85, 71-88, 2007.

Andersson, C., Pausata, F. S. R., Jansen, E., Risebrobakken, B., and Telford, R. J.: Holocene trends in the foraminifer record from the Norwegian Sea and the North Atlantic Ocean, Clim. Past, 6, 179-193, doi:10.5194/cp-6-179-2010, 2010.

Annan, J. D. and Hargreaves, J. C.: Understanding the CMIP3 multimodel ensemble, J. Climate, 24, 4529-4538, 2011.

Arbuthnott, J.: An argument for Divine Providence, taken from the constant regularity observed in the births of both sexes, Phil. Trans., 27, 186-190, 1710.

Barron, J. A. and Bukry, D.: Solar forcing of Gulf of California climate during the past $2000 \mathrm{yr}$ suggested by diatoms and silicoflagellates, Mar. Micropaleontol., 62, 115-139, 2007.

Bergthorsson, P.: An estimate of ice drift and temperature in 1000 years, Jökull, 19, 94-101, 1969.

Bernabo, J. C.: Quantitative estimates of temperature changes over the last 2700 years in Michigan based on pollen data, Quaternary Res., 15, 143-159, 1981.

Bird, B. W., Abbott, M. B., Finney, B. P., and Kutchko, B.: A 2000 year varve-based climate record from the central Brooks Range, Alaska, J. Paleolimnology, 41, 25-41, 2008.

Black, D. E., Abahazi, M. A., Thunell, R. C., Kaplan, A., Tappa, E. J., and Peterson, L. C.: An 8-century tropical Atlantic SST record from the Cariaco Basin: Baseline variability, twentieth-century warming, and Atlantic hurricane frequency, Paleoceanography, 22, PA4204, doi:10.1029/2007PA001427, 2007.

Bradley, R. S.: Paleoclimatology: Reconstructing climates of the Quaternary, Academic Press, San Diego, CA, 1999.

Bradley, R. S., Hughes, M. K., and Diaz, H. F.: Climate in medieval time, Science, 302, 404-405, 2003.

Briffa, K. R.: Annual climate variability in the Holocene: interpreting the message of ancient trees, Quaternary Sci. Rev., 19, 87-105, 2000.

Briffa, K. R., Osborn, T. J., Schweingruber, F. H., Jones, P. D., Shiyatov, S. G., and Vaganov, E. A.: Tree-ring width and density data around the Northern Hemisphere: Part 1, local and regional climate signals, Holocene, 12, 737-757, 2002.

Briffa, K. R., Shishov, V. V., Melvin, T. M., Vaganov, E. A., Grudd, H., Hantemirov, R. M., Eronen, M., and Naurzbaev, M. M.: Trends in recent temperature and radial tree growth spanning 2000 years across northwest Eurasia, Philos. T. R. Soc. B, 363, 2271-2284, 2008.

Broecker, W. S.: Was the Medieval Warm Period global?, Science, 291, 1497-1499, 2001

Brohan, P., Kennedy, J. J., Harris, I., Tett, S. F. B., and Jones, P. D. Uncertainty estimates in regional and global observed temperature changes: a new dataset from 1850, J. Geophys. Res., 111, D12106, doi:10.1029/2005jd006548, 2006.

Büntgen, U., Frank, D. C., Nievergelt, D., and Esper, J.: Summer temperature variations in the European Alps, A.D. 755-2004, J. Climate, 19, 5606-5623, 2006.

Büntgen, U., Tegel, W., Nicolussi, K., McCormick, M., Frank, D., Trouet, V., Kaplan, J. O., Herzig, F., Heussner, K.-U., and Wanner, H.: 2500 years of European climate variability and human susceptibility, Science, 331, 578-582, 2011.

Callendar, G. S.: The artificial production of carbon dioxide and its influence on climate, Q. J. Roy. Meteorol. Soc., 64, 223-240, 1938.

Christiansen, B. and Ljungqvist, F. C.: Reconstruction of the extratropical $\mathrm{NH}$ mean temperature over the last millennium with a method that preserves low-frequency variability, J. Climate, 24, 6013-6034, 2011

Clegg, B. F., Clarke, G. H., Chipman, M. L., Chou, M., Walker, I. R., Tinner, W., and Hu, F. S.: Six millennia of summer temperature variation based on midge analysis of lake sediments from Alaska, Quaternary Sci. Rev., 29, 3308-3316, 2010.

Collins, M.: Ensembles and probabilities: a new era in the prediction of climate change, Philos. T. R. Soc. A, 365, 1957-1970, 2007.

Cook, T. L., Bradley, R. S., Stoner, J. S., and Francus, P.: Five thousand years of sediment transfer in a high arctic watershed recorded in annually laminated sediments from Lower Murray Lake, Ellesmere Island, Nunavut, Canada, J. Paleolimnology, 41, 77-94, 2009.

Corona, C., Edouard, J.-L., Guibal, F., Guiot, J., Bernard, S., Thomas, A., and Denelle, N.: Long-term summer (AD 7512008) temperature fluctuation in the French Alps based on treering data, Boreas, 40, 351-366, 2011.

Cronin, T. M., Dwyer, G. S., Kamiya, T., Schwede, S., and Willard, D. A.: Medieval Warm Period, Little Ice Age and 20th century temperature variability from Chesapeake Bay, Global Planet. Change, 36, 17-29, 2003.

Crowley, T. J.: Causes of climate change over the past 1000 years, Science, 289, 270-277, 2000.

Crowley, T. J. and Lowery, T.: How Warm Was the Medieval Warm Period? A comment on "Man-made versus natural climate change", Ambio, 29, 51-54, 2000.

D'Andrea, W. J., Huang, Y., Fritz, S. C., and Anderson, N. J.: Abrupt Holocene climate change as an important factor for human migration in West Greenland, Proc. Natl. Acad. Sci. USA, 108, 9765-9769, 2011.

D’Arrigo, R., Jacoby, G., Frank, D., Pederson, N., Cook, E., Buckley, B., Nachin, B., Mijiddorj, R., and Dugarjav, C.: 1738 years of Mongolian temperature variability inferred from a tree-ring 
width chronology of Siberian pine, Geophys. Res. Lett., 28, 543546, 2001.

D'Arrigo, R., Wilson, R., and Jacoby, G.: On the long-term context for late twentieth century warming, J. Geophys. Res., 111, D03103, doi:10.1029/2005JD006352, 2006.

D’Arrigo, R. D., Jacoby, G., Buckley, B. M., Sakulich, J. Frank, D., Wilson, R., Curtis, A., and Anchukaitis, K. J.: Tree growth and inferred temperature variability at the North American Arctic treeline, Glob. Planet. Change, 65, 71-82, 2009.

Delworth, T. L. and Knutson, T.R.: Simulation of early 20th century global warming, Science, 287, 2246-2250, 2000.

Diaz, H. F., Trigo, R., Hughes, M. K., Mann, M. E., Xoplaki, E., and Barriopedro, D: Spatial and temporal characteristics of climate in Medieval times revisited, B. Am. Meteorol. Soc., 92, 1487-1500, 2011.

Divine, D., Isaksson, E., Martma, T., Meijer, H. A. J., Moore, J., Pohjola, V., van de Wal, R. S. W., and Godtliebsen, F.: Thousand years of winter surface air temperature variations in Svalbard and northern Norway reconstructed from ice core data, Polar Res., 30, 1-12, 2011.

Doose-Rolinski, H., Rogalla, U., Scheeder, G., Lücke, A., and von Rad, U.: High resolution temperature and evaporation changes during the late Holocene in the northeastern Arabian Sea, Paleoceanography, 16, 358-367, 2001.

Edwards, T. W. D., Birks, S. J., Luckman, B. H., and MacDonald, G. M.: Climatic and hydrologic variability during the past millennium in the eastern Rocky Mountains and northern Great Plains of western Canada, Quaternary Res., 70, 188-197, 2008.

Emeis, K. C. and Dawson, A. G.: Holocene palaeoclimatic records over Europe and the North Atlantic, Holocene, 13, 305-309, 2003.

Esper, J. and Frank, D.C.: IPCC on heterogeneous Medieval Warm Period, Climatic Change, 94, 267-273, 2009.

Esper, J., Cook, E. R., and Schweingruber, F. H.: Low-frequency signals in long tree-ring chronologies for reconstructing past temperature variability, Science, 295, 2250-2253, 2002.

Esper, J., Schweingruber, F. H., and Winiger, M.: 1300 years of climatic history for Western Central Asia inferred from tree-rings, Holocene, 12, 267-277, 2003.

Filippi, M. L., Lambert, P., Hunziker, J., Kubler, B., and Bernasconi, S.: Climatic and anthropogenic influence on the stable isotope record from bulk carbonates and ostracodes in Lake Neuchatel, Switzerland, during the last two millennia, J. Paleolimnology, 21, 19-34, 1999.

Fisher, D. A., Koerner, R. M., Paterson, W. S. B., Dansgaard, W., Gundestrup, N., and Reeh, N.: Effect of wind scouring on climatic records from icecore oxygen isotope profiles, Nature, 301, 205-209, 1983.

Frisia, S., Borsato, A., Spötl, C., Villa, I. M., and Cucchi, F.: Climate variability in the SE Alps of Italy over the past 17000 years reconstructed from a stalagmite record, Boreas, 34, 445$455,2005$.

Gajewski, K.: Late-Holocene climates of eastern North America estimated from pollen data, Quaternary Res., 29, 255-262, 1988.

Ge, Q. S., Zheng, J. Y., Fang, X. Q., Man, Z. M., Zhang, X. Q., Zhang, P. Y., and Wang, W. C.: Winter half-year temperature reconstruction for the middle and lower reaches of the Yellow River and Yangtze River, China, during the past 2000 years, Holocene, 13, 933-940, 2003.
Ge, Q. S., Wang, S. B., and Zheng, J. Y.: Reconstruction of temperature series in China for the last 5000 yr, Prog. Nat. Sci., 16, 838-845, 2006.

Ge, Q.-S., Zheng, J.-Y., Hao, Z.-X., Shao, X.-M., Wang, W.C., and Luterbacher, J.: Temperature variation through 2000 years in China: An uncertainty analysis of reconstruction and regional difference, Geophys. Res. Lett., 37, L03703, doi:10.1029/2009GL041281, 2010.

Geirsdóttir, A., Miller, G. H., Thordarson, T., and Ólafsdóttir, K. B.: A 2000 year record of climate variations reconstructed from Haukadalsvatn, West Iceland, J. Paleolimnology, 41, 95-115, 2009.

Goni, M. A., Woodworth, M. P., Aceves, H. L., Thunell, R. C., Tappa, E., Black, D., Müller-Karger, F., Astor, Y., and Varela, R.: Generation, transport, and preservation of the alkenone-based $\mathrm{U}_{37}^{\mathrm{K}^{\prime}}$ sea surface temperature index in the water column and sediments of the Cariaco Basin (Venezuela), Global Biogeochem. Cy., 18, GB2001, doi:10.1029/2003GB002132, 2004.

Goosse, H., Arzel, O., Luterbacher, J., Mann, M. E., Renssen, H., Riedwyl, N., Timmermann, A., Xoplaki, E., and Wanner, H.: The origin of the European "Medieval Warm Period", Clim. Past, 2, 99-113, doi:10.5194/cp-2-99-2006, 2006.

Goosse, H., Guiot, J., Mann, M. E., Dubinkina, S., and SallazDamaz, Y.: The medieval climate anomaly in Europe: Comparison of the summer and annual mean signals in two reconstructions and in simulations with data assimilation, Global Planet. Change, in press, doi:10.1016/j.gloplacha.2011.07.002, 2012.

Graham, N. E., Ammann, C. M., Fleitmann, D., Cobb, K. M., and Luterbacher, J.: Support for global climate reorganization during the "Medieval climate anomaly", Clim. Dynam., 37, 1217-1245, 2011.

Grootes, P. M. and Stuiver, M.: Oxygen 18/16 variability in Greenland snow and ice with $10^{3}$ to $10^{5}$-year time resolution, J. Geophys. Res., 102, 26455-26470, 1997.

Grove, J. M.: The Little Ice Age, Methuen, London, 2nd Edn., 1988.

Grudd, H.: Torneträsk tree-ring width and density AD 500-2004: a test of climatic sensitivity and a new 1500-year reconstruction of north Fennoscandian summers, Clim. Dynam., 31, 843-857, 2008.

Graumlich, L. J.: A 1000-yr record of temperature and precipitation in the Sierra Nevada, Quaternary Res., 39, 249-255, 1993.

Guiot, J.: A robust spatial reconstruction of April to September temperature in Europe: Comparisons between the medieval period and the recent warming with a focus on extreme values, Global Planet. Change, in press, doi:10.1016/j.gloplacha.2011.07.007, 2012.

Guiot, J., Corona, C., and ESCARSEL members: Growing season temperatures in Europe and climate forcings over the past 1400 years, PLoS ONE, 5, e9972, doi:10.1371/journal.pone.0009972, 2010.

Haltia-Hovi, E., Saarinen, T., and Kukkonen, M.: A 2000-year record of solar forcing on varved lake sediment in eastern Finland, Quaternary Sci. Rev., 26, 678-689, 2007.

Helama, S., Fauria, M., Mielikäinen, K., Timonen, M., and Eronen, M.: Sub-Milankovitch solar forcing of past climates: mid and late Holocene perspectives, Bull. Geol. Soc. Am., 122, 19811988, 2010.

Hegerl, G., Crowley, T., Allen, M., Hyde, W., Pollack, H., Smer- 
don, J., and Zorita, E.: Detection of human influence on a new, validated, 1500 year temperature reconstruction, J. Climate, 20, 650-666, 2007.

Hong, B., Liu, C.-Q., Lin, Q.-H., Yasuyuki, S., Leng, X.-T., Wang, Y., Zhu, Y.-X., and Hong, Y.-T.: Temperature evolution from the $\delta^{18} \mathrm{O}$ record of Hani peat, Northeast China, in the last 14000 years, Sci. China D: Earth Sciences, 52, 952-964, 2009.

Hong, Y. T., Jiang, H. B., Liu, T. S., Zhou, L. P., Beer, J., Li, H. E., Leng, X. T., Hong, B., and Qin, X. G.: Response of climate to solar forcing recorded in a 6000 -year $\delta^{18} \mathrm{O}$ time-series of Chinese peat cellulose, Holocene, 10, 1-7, 2000.

Hu, F. S., Ito, E., Brown, T. A., Curry, B. B., and Engstrom, D. R.: Pronounced climatic variations in Alaska during the last two millennia, Proc. Natl. Acad. Sci. USA, 98, 10552-10556, 2001.

Hughes, M. K. and Diaz, H. F.: Was there a "medieval warm period", and if so, where and when?, Climatic Change, 26, 109$142,1994$.

Jansen, E., Overpeck, J., Briffa, K., Duplessy, J.-C., Joos, F., Masson-Delmotte, V., Olago, D., Otto-Bliesner, B., Peltier, W., Rahmstorf, S., Ramesh, R., Raynaud, D., Rind, D., Solomina, O., Villalba, R., and Zhang, D.: Palaeoclimate, in: Climate Change 2007: The Physical Science Basis. Contribution of Working Group I to the Fourth Assessment Report of the Intergovernmental Panel on Climate Change, edited by: Solomon, S., Qin, D., Manning, M., Chen, Z., Marquis, M., Averyt, K., Tignor, M., and Miller, H., chap. 6, Cambridge University Press, Cambridge, United Kingdom and New York, NY, USA, 2007.

Jennings, A. E. and Weiner, N. J.: Environmental change in eastern Greenland during the last 1300 years: evidence from foraminifera and lithofacies in Nansen Fjord, $68^{\circ} \mathrm{N}$, Holocene, 6, 179-191, 1996.

Jensen, K. G., Kuijpers, A., Koç, N., and Heinemeier, J.: Diatom evidence of hydrografhic changes and ice conditions in Igaliku Fjord, South Greenland, during the past 1500 years, Holocene, 14, 152-164, 2004.

Jiang, J., Eiriksson, M., Schultz, K. L., Knudsen, K.-L., and Seidenkrantz, M.-S.: Evidence for solar forcing of sea surface temperature on the North Icelandic Shelf during the late Holocene, Geology, 33, 73-76, 2005.

Jones, P. D. and Mann, M. E.: Climate over past millennia, Rev. Geophys., 42, RG2002, doi:10.1029/2003RG000143, 2004.

Jones, P. D., Osborn, T. J., and Briffa, K. R.: Estimating sampling errors in large-scale temperature averages, J. Climate, 10, 25482568, 1997.

Jones, P. D., Briffa, K. R., Barnett, T. P., and Tett, S. F. B.: Highresolution paleoclimatic records for the last millennium: Interpretation, integration and comparison with general circulation model control-run temperatures, Holocene, 8, 455-471, 1998.

Juckes, M. N., Allen, M. R., Briffa, K. R., Esper, J., Hegerl, G. C., Moberg, A., Osborn, T. J., and Weber, S. L.: Millennial temperature reconstruction intercomparison and evaluation, Clim. Past, 3, 591-609, doi:10.5194/cp-3-591-2007, 2007.

Kalugin, I. A., Daryin, A. V., and Babich, V. V.: Reconstruction of annual air temperatures for three thousand years in Altai region by lithological and geochemical indicators in Teletskoe Lake sediments, Dokl. Earth Sci., 426, 681-684, 2009.

Kaufman, D. S., Schneider, D. P., McKay, N. P., Ammann, C. M., Bradley, R. S., Briffa, K. R., Miller, G H., Otto-Bliesner, B. L., Overpeck, J. T., and Vinther, B. M.: Recent warming reverses long-term Arctic cooling, Science, 325, 1236-1239, 2009.

Keigwin, L. D.: The Little Ice Age and Medieval Warm Period in the Sargasso Sea, Science, 274, 1504-1508, 1996.

Keigwin, L. D., Sachs, J. P., and Rosenthal, Y.: A 1600-year History of the Labrador Current off Nova Scotia, Clim. Dynam., 21, 5362, 2003.

Kitagawa, H. and Matsumoto, E.: Climatic implications of $\delta^{13} \mathrm{C}$ variations in a Japanese cedar (Cryptomeria japonica) during the last two millennia, Geophys. Res. Lett., 22, 2155-2158, 1995.

Klimanov, V. A., Khotinsky, N. A., and Blagoveshenskaya, N. V.: Climate fluctuations during the historical times in the center of Russian Plain, Izvestiya of Russian Academy of Sciences, Geographical Series, 1, 89-96, 1995 (in Russian).

Klimenko, V. V. and Sleptsov, A. M.: Multi-proxy reconstruction of the climate of Eastern Europe during the last 2,000 years, Izvestiya of the Russian Geographical Society, 6, 45-54, 2003 (in Russian).

Klimenko, V. V., Klimanov, V. A., Sirin, A. A., and Sleptsov, A. M.: Climate Changes in Western European Russia in the Late Holocene, Dokl. Earth Sci., 377, 190-194, 2001.

Knutti, R., Furrer, R., Tebaldi, C., Cermak, J., and Meehl. G. A.: Challenges in combining projections from multiple climate models, J. Climate, 23, 2739-2758, 2010.

Kobashi, T., Severinghaus, J. P., Barnola, J.-M., Kawamura, K., Carter, T., and Nakaegawa, T.: Persistent multi-decadal Greenland temperature fluctuation through the last millennium, Climatic Change, 100, 733-756, 2010.

Lamb, H. H.: The early medieval warm epoch and its sequel, Palaeogeogr. Palaeocl., 1, 13-37, 1965.

Lamoureux, S. F. and Bradley, R. S.: A late Holocene varved sediment record of environmental change from northern Ellesmere Island, Canada, J. Paleolimnology, 16, 239-255, 1996.

Lauritzen, S.-E. and Lundberg, J.: Calibration of the speleothem delta function: an absolute temperature record for the Holocene in northern Norway, Holocene, 9, 659-669, 1999.

Lee, H. F. and Zhang, D. D.: Relationship between NAO and drought disasters in northwestern China in the last millennium, J. Arid Environ., 75, 1114-1120, 2011.

LiJuan, L., Wang, B., and Zhou, T.: Impacts of external forcing on the 20th century global warming, Chin. Sci. Bull., 52, 31483154, 2007.

Linderholm, H. W. and Gunnarson, B. E.: Summer temperature variability in central Scandinavia during the last 3600 years. Geogr. Ann., 87A, 231-241, 2005.

Linge, H., Lauritzen, S.-E., Lundberg, J., and Berstad, I. M.: Stable isotope stratigraphy of Holocene speleothems: examples from a cave system in Rana, northern Norway, Palaeogeogr. Palaeocl., 167, 209-224, 2001.

Linge, H., Lauritzen, S.-E., Andersson, C., Hansen, J. K., Skoglund, R. Ø., and Sundqvist, H. S.: Stable isotope records for the last 10000 years from Okshola cave (Fauske, northern Norway) and regional comparisons, Clim. Past, 5, 667-682, doi:10.5194/cp-5667-2009, 2009.

Liu, Y., An, Z., Linderholm, H. W., Chen, D., Song, H., Cai, Q., Sun, J., Li, Q., and Tian, H.: Annual temperatures during the last 2485 years in the Eastern Tibetan Plateau inferred from tree rings, Sci. China D, 52, 348-359, 2009.

Liu, Z., Henderson, A. C. G., and Huang, Y.: Alkenone-based reconstruction of late-Holocene surface temperature and salin- 
ity changes in Lake Qinghai, China, Geophys. Res. Lett., 33, L09707, doi:10.1029/2006GL026151, 2006.

Ljungqvist, F. C.: A new reconstruction of temperature variability in the extra-tropical Northern Hemisphere during the last two millennia, Geogr. Ann., 92A, 339-351, 2010.

Lloyd, A. H. and Graumlich, L. J.: Holocene dynamics of treeline forests in the Sierra Nevada, Ecology, 78, 1199-1210, 1997.

Loso, M. G.: Summer temperatures during the Medieval Warm Period and Little Ice Age inferred from varved proglacial lake sediments in southern Alaska, J. Paleolimnology, 41, 117-128, 2009.

Lou, J. Y. and Chen, C. T. A.: Paleoclimatological and palaeoenvironmental records since $4000 \mathrm{BP}$ in the sediments of alpine lakes in Taiwan, Sci. China D, 40, 424-462, 1997.

Luckman, B. H. and Wilson, R. J. S.: Summer temperatures in the Canadian Rockies during the last millennium: a revised record, Clim. Dynam., 24, 131-144, 2005.

Lund, D. C. and Curry, W.: Florida Current surface temperature and salinity variability during the last millennium, Paleoceanography, 21, PA2009, doi:10.1029/2005PA001218, 2006.

Luterbacher, J., García-Herrera, R., Akcer-On, S., Allan, R., M. Alvarez-Castro, C., Benito, G., Booth, J., Büntgen, U., Cagatay, N., Colombaroli, D., Davis, B., Esper, J., Felis, T., Fleitmann, D., Frank, D., Gallego, D., Garcia-Bustamante, E., Glaser, R., González-Rouco, J. F., Goosse, H., Kiefer, T., Macklin, M. G., Manning, S., Montagna, P., Newman, L., Power, M. J., Rath, V., Ribera, P., Riemann, D., Roberts, N., Silenzi, S., Tinner, W., Valero-Garces, B., van der Schrier, G., Tzedakis, C., Vannière, B., Vogt, S., Wanner, H., Werner, J. P., Willett, G., Williams, M. H., Xoplaki, E., Zerefos, C. S., and Zorita, E.: A review of 2000 years of palaeoclimatic evidence in the Mediterranean, in: The Mediterranean Climate: from past to future, edited by: Lionello, P., Elsevier, Amsterdam, The Netherlands, in press, 2012.

Mangini, A., Spötl, C., and Verdes, P.: Reconstruction of temperature in the Central Alps during the past $2000 \mathrm{yr}$ from a $\delta^{18} \mathrm{O}$ stalagmite record, Earth. Planet. Sci. Lett., 235, 741-751, 2005.

Mann, M. E. and Jones, P. D.: Global surface temperatures over the past two millennia, Geophys. Res. Lett., 30, 1820, doi:10.1029/2003GL017814, 2003.

Mann, M. E., Bradley, R. S., and Hughes, M. K.: Global-scale temperature patterns and climate forcing over the past six centuries, Nature, 392, 779-787, 1998.

Mann, M. E., Bradley, R. S., and Hughes, M. K.: Northern Hemisphere temperatures during the past millennium: Inferences, uncertainties, and limitations, Geophys. Res. Lett., 26, 759-762, 1999.

Mann, M. E., Zhang, Z., Hughes, M. K., Bradley, R. S., Miller, S. K., Rutherford, S., and Ni, F.: Proxy-based reconstructions of hemispheric and global surface temperature variations over the past two millennia, Proc. Natl. Acad. Sci. USA, 105, 1325213257, 2008.

Mann, M. E., Zhang, Z., Rutherford, S., Bradley, R. S., Hughes, M. K., Shindell, D., Ammann, C., Faluvegi, G., and Ni, F.: Global signatures and dynamical origins of the Little Ice Age and Medieval Climate Anomaly, Science, 326, 1256-1260, 2009.

Martín-Chivelet, J., Muñoz-García, M. B., Edwards, R. L., Turrero, M. J., and Ortega, A. I.: Land surface temperature changes in Northern Iberia since $4000 \mathrm{yr} \mathrm{BP}$, based on $\delta^{13} \mathrm{C}$ of speleothems, Global Planet. Change, 77, 1-12, 2011.

Martínez-Cortizas, A., Pontevedra-Pombal, X., Garcia-Rodeja, E.,
Novoa-Muñoz, J. C., and Shotyk, W.: Mercury in a Spanish peat bog: Archive of climate change and atmospheric metal deposition, Science, 284, 939-942, 1999.

Masson, D. and Knutti, R.: Spatial-scale dependence of climate model performance in the CMIP3 ensemble, J. Climate, 24, 2680-2692, 2011.

Matthews, J. A. and Briffa, K. R.: The Little Ice Age: Re-evaluation of an evolving concept, Geogr. Ann., 87A, 17-36, 2005.

McKay, N. P., Kaufman, D. S., and Michelutti, N.: Biogenic silica concentration as a high-resolution, quantitative temperature proxy at Hallet Lake, south-central Alaska, Geophys. Res. Lett., 35, L05709, doi:10.1029/2007GL032876, 2008.

Millet, L., Arnaud, F., Heiri, O., Magny, M., Verneaux, V., and Desmet, M.: Late-Holocene summer temperature reconstruction from chironomid assemblages of Lake Anterne, northern French Alps, Holocene, 19, 317-328, 2009.

Moberg, A., Sonechkin, D. M., Holmgren, K., Datsenko, N. M., and Karlén, W.: Highly variable Northern Hemisphere temperatures reconstructed from low- and high-resolution proxy data, Nature, 433, 613-617, 2005.

Moore, J. J., Hughen, K. A., Miller, G. H., and Overpeck, J. T.: Little Ice Age recorded in summer temperature reconstruction from varved sediments of Donard Lake, Baffin Island, Canada, J. Paleolimnology, 25, 503-517, 2001.

Naurzbaev, M. M., Vaganov, E. A., Sidorova, O. V., and Schweingruber, F. H.: Summer temperatures in eastern Taimyr inferred from a 2427-year late-Holocene tree-ring chronology and earlier floating series, Holocene, 12, 727-736, 2002.

Neukom, R. and Gergis, J.: Southern Hemisphere high-resolution palaeoclimate records of the last 2000 years, Holocene, doi:10.1177/0959683611427335, in press, 2012.

Neukom, R., Luterbacher, J., Villalba, R., Küttel, M., Frank, D., Jones, P., Grosjean, M., Wanner, H., Aravena, J.-C., Black, D., Christie, D., D’Arrigo, R., Lara, A., Morales, M., Soliz-Gamboa, C., Srur, A., Urrutia, R., and von Gunten, L.: Multiproxy summer and winter surface air temperature field reconstructions for Southern South America covering the past centuries, Clim. Dynam., 37, 35-51, 2011.

NGRIP members: High-resolution record of Northern Hemisphere climate extending into the last interglacial period, Nature, 431, 147-151, 2004.

Nyberg, J., Malmgren, B. A., Kuijpers, A., and Winter, A.: A centennial-scale variability of tropical North Atlantic surface hydrography during the late Holocene, Palaeogeogr. Palaeoclimatol. Palaeocol., 183, 25-41, 2002.

Ojala, A. E. K. and Alenius, T.: 10,000 years of interannual sedimentation recorded in the Lake Nautajärvi (Finland) clasticorganic varves, Palaeogeogr. Palaeocl. 219, 285-302, 2005.

Oppo, D. W., Rosenthal, Y., and Linsley, B. K.: 2,000-year-long temperature and hydrology reconstructions from the Indo-Pacific warm pool, Nature, 460, 1113-1116, 2009.

Osborn, T. J. and Briffa, K. R.: The spatial extent of 20th-century warmth in the context of the past 1200 years, Science, 313, 841844, 2006.

Park, J.: A modern pollen-temperature calibration dataset from Korea and quantitative temperature reconstructions for the Holocene, Holocene, 21, 1125-1135, 2011.

Pla, S. and Catalan, J.: Chrysophyte cysts from lake sediments reveal the submillennial winter/spring climate variability in the 
northwestern Mediterranean region throughout the Holocene, Clim. Dynam., 24, 263-278, 2005.

Popa, I. and Kern, Z.: Long-term summer temperature reconstruction inferred from tree-ring records from the Eastern Carpathians, Clim. Dynam., 32, 1107-1117, 2009.

Qiang, M.-R., Chen, F.-H., Zhang, J.-W., Gao, S.-Y., and Zhou, A.-F.: Climatic changes documented by stable isotopes of sedimentary carbonate in Lake Sugan, northeastern Tibetan Plateau of China, since 2 ka BP, Chin. Sci. Bull., 50, 1930-1939, 2005.

Ran, L., Jiang, H., Knudsen, K. L., and Eiríksson, J.: Diatom-based reconstruction of palaeoceanographic changes on the North Icelandic shelf during the last millennium, Palaeogeogr. Palaeocl., 302, 109-119, 2011.

Richey, J. N., Poore, R. Z., Flower, B. P., and Quinn, T. M.: 1400 yr multi-proxy record of climate variability from the northern Gulf of Mexico, Geology, 35, 423-426, 2007.

Salzer, M. W. and Kipfmueller, K. F.: Reconstructed temperature and precipitation on a millennial timescale from tree-rings in the Southern Colorado Plateau, USA, Climatic Change, 70, 465487, 2005.

Schmidt, R., Kamenik, C., and Roth, M.: Siliceous algae-based seasonal temperature inference and indicator pollen tracking ca. 4,000 years of climate/land use dependency in the southern Austrian Alps, J. Paleolimnology, 38, 541-554, 2007.

Sicre, M.-A., Hall, I. R., Mignot, J., Khodri, M., Ezat, U., Truong, M.-X., Eiríksson, J. J., and Knudsen, K.-L.: Sea surface temperature variability in the subpolar Atlantic over the last two millennia, Paleoceanography, 26, PA4218, doi:10.1029/2011PA002169, 2011.

Solomina, O. and Alverson, K.: High latitude Eurasian paleoenvironments: introduction and synthesis, Palaeogeogr. Palaeocl., 209, 1-18, 2004.

Sümegi, P., Jakab, G., Majkut, P., Törõcsik, T., and Zatykó, Cs.: Middle Age palaeoecological and palaeoclimatological reconstruction in the Carpathian Sea, Idõjárás, 113, 265-298, 2009.

Sundqvist, H. S., Holmgren, K., Moberg, A., Spötl, C., and Mangini, A.: Stable isotopes in a stalagmite from NW Sweden document environmental changes over the past 4000 years, Boreas, 39, 77-86, 2010.

Tan, M., Liu, T. S., Hou, J., Qin, X., Zhang, H., and Li, T.: Cyclic rapid warming on centennial-scale revealed by a 2650 -year stalagmite record of warm season temperature, Geophys. Res. Lett., 30, 1617, doi:10.1029/2003GL017352, 2003.

Taricco, C., Ghil, M., Alessio, S., and Vivaldo, G.: Two millennia of climate variability in the Central Mediterranean, Clim. Past., 5, 171-181, doi:10.5194/cp-5-171-2009, 2009.

Tebaldi, C. and Knutti, R.: The use of the multi-model ensemble in probabilistic climate projections, Philos. T. R. Soc. A, 365, 2053-2075, 2007.

Tett, S. F. B., Jones, G. S., Stott, P. A., Hill, D. C., Mitchell, J. F. B., Allen, M. A., Ingram, W. J., Johns, T. C., Johnson, C. E., Jones, A., Roberts, D. L., Sexton, D. M. H., and Woodage, M. J.: Estimation of natural and anthropogenic contributions to twentieth century temperature change, J. Geophys. Res., 107, 4306, doi:10.1029/2000JD000028, 2002.

Thomas, E. K. and Briner, J. P.: Climate of the past millennium inferred from varved proglacial lake sediments on northeast Baffin Island, Arctic Canada, J. Paleolimnology, 41, 209-224, 2009.

Thompson, L. G., Mosley-Thompson, E., Brecher, H., Davis, M.
E., Leon, B., Les, D., Mashiotta, T. A., Lin, P.-N., and Mountain, K.: Evidence of abrupt tropical climate change: past and present, Proc. Natl. Acad. Sci. USA, 103, 10536-10543, 2006.

Tiljander, M., Karhu, J. A., and Kauppila, T.: Holocene records of carbon and hydrogen isotope ratios of organic matter in annually laminated sediments of Lake Korttajärvi, central Finland, J. Paleolimnology, 36, 233-243, 2006.

Treydte, K. S., Frank, D. C., Saurer, M., Helle, G., Schleser, G. H., and Esper, J.: Impact of climate and $\mathrm{CO}_{2}$ on a millennium-long tree-ring carbon isotope record, Geochim. Cosmochim. Acta, 73, 4635-4647, 2009.

Tuovinen, M., McCarroll, D., Grudd, H., Jalkanen, R., and Los, S.: Spatial and temporal stability of the climatic signal in northern Fennoscandian pine tree ring width and maximum density, Boreas, 38, 1-12, 2009.

van Engelen, A. F. V., Buisman, J., and IJnsen, F.: A millennium of weather, winds and water in the Low Countrie, in: History and Climate: Memories of the Future?, edited by: Jones, P. D. Ogilvie, A. E. J., Davies, T. D., and Briffa, K. R., Kluwer Academic/Plenum Publishers, New York, Boston, Dordrecht, London, Moscow, 101-124, 2001.

Vinther, B. M., Clausen, H. B., Johnsen, S. J., Rasmussen, S. O., Andersen, K. K., Buchardt, S. L., Dahl-Jensen, D., Seierstad, I. K., Siggaard-Andersen, M.-L., Steffensen, J. P., Svensson, A. M., Olsen, J., and Heinemeier, J.: A synchronized dating of three Greenland ice cores throughout the Holocene, J. Geophys. Res., 111, D13102, doi:10.1029/2005JD006921, 2006.

Vinther, B. M., Clausen, H. B., Fisher, D. A., Koerner, R. M., Johnsen, S. J., Andersen, K. K., Dahl-Jensen, D., Rasmussen, S. O., Steffensen, J. P., and Svensson, A. M.: Synchronizing ice cores from the Renland and Agassiz ice caps to the Greenland Ice Core Chronology, J. Geophys. Res., 113, D08115, doi:10.1029/2007JD009143, 2008.

Vinther, B. M., Jones, P. D., Briffa, K. R., Clausen, H. B., Andersen, K. K., Dahl-Jensen, D., and Johnsen, S. J.: Climatic signals in multiple highly resolved stable isotope records from Greenland, Quaternary Sci. Rev., 29, 522-538, 2010.

Wang, S. W., Wen, X. Y., Luo, Y., Dong, W.-J., Zhao, Z.-C., and Yang, B.: Reconstruction of temperature series of China for the last 1000 yr, Chinese Sci. Bull., 52, 3272-3280, 2007.

Wanner, H., Beer, J., Bütikofer, J., Crowley, T., Cubasch, U., Flückiger, J., Goosse, H., Grosjean, M., Joos, F., Kaplan, J. O., Küttel, M., Müller, S., Pentice, C., Solomina, O., Stocker, T., Tarasov, P., Wagner, M., and Widmann, M.: Mid to late Holocene climate change - an overview, Quaternary Sci. Rev., 27, 17911828, 2008.

Wanner, H., Solomina, O., Grosjean, M., Ritz, S. P., and Jetel, M.: Structure and origin of Holocene cold events, Quaternary Sci. Rev., 30, 3109-3123, 2011.

Wessel, P. and Smith, W. H. F.: New, improved version of the Generic Mapping Tools released, EOS Trans., AGU, 79, 579, doi:10.1029/98EO00426, 1998.

Wilks, D. S.: Resampling hypothesis tests for autocorrelated fields, J. Climate, 11, 65-82, 1997.

Willemse, N. W. and Tornqvist, T. E.: Holocene century-scale temperature variability from West Greenland lake records, Geology, 27, 580-584, 1999.

Wilson, R., D’Arrigo, R., Buckley, B., Büntgen, U., Esper, J., Frank, D., Luckman, B., Payette, S., Vose, R., and Young- 
blut, D.: A matter of divergence - tracking recent warming at hemispheric scales using tree-ring data, J. Geophys. Res., 112, D17103, doi:10.1029/2006JD008318, 2007.

Wilson, R., Cook, E., D’Arrigo, R., Riedwyl, N., Evans, M. N., Tudhope, A., and Allan, R.: Reconstructing ENSO: the influence of method, proxy data, climate forcing and teleconnections, J. Quaternary Sci., 25, 62-78, 2010.

Wirtz, K. W., Lohmann, G., Bernhardt, K., and Lemmen, C.: Mid-Holocene regional reorganization of climate variability: Analyses of proxy data in the frequency domain, Palaeogeogr. Palaeocl., 298, 189-200, 2010.

Xu, Q. H., Xiao, J. L., Nakamura, T., Yang, X. L., Yang, Z. J., Liang, W. D., Inouchi, Y., and Yang, X. Y.: Quantitative reconstructed climatic changes of Daihai basin by pollen data, Mar. Geol. Quat. Geoi, 23, 99-108, 2003 (in Chinese).
Yadav, R. R., Braeuning, A., and Singh, J.: Tree ring inferred summer temperature variations over the last millennium in western Himalaya, India, Clim. Dynam., 36, 1545-1554, 2011.

Yang, B., Braeuning, A., and Johnson, K. R.: General characteristics of temperature variation in China during the last two millennia, Geophys. Res. Lett., 29, 381-384, 2002.

Yang, B., Braeuning, A., and Shi, Y. F.: Late Holocene temperature fluctuations on the Tibetan Plateau, Quaternary Sci. Rev., 22, 2335-2344, 2003.

Zhang, Q.-B., Cheng, G., Yao, T., Kang, X., and Huang, J.: A 2,326-year tree-ring record of climate variability on the northeastern Qinghai-Tibetan Plateau, Geophys. Res. Lett., 30, 17391742, 2003.

Zhang, Q., Gemmer, M., and Chen, J.: Climate changes and flood/drought risk in the Yangtze Delta, China, during the past millennium, Quaternary Int., 176-177, 62-69, 2008. 